\title{
Immunotherapy for gliomas: shedding light on progress in preclinical and clinical development
}

\author{
Maria B. Garcia-Fabiani, Maria Ventosa, Andrea Comba, Marianela Candolfi, \\ Alejandro J. Nicola Candia, Mahmoud Alghamri, Padma Kadiyala, Stephen \\ Carney, Syed M. Faisal, Anna Schwendeman, James J. Moon, Lindsay Scheetz, \\ Joerg Lahann, Ava Mauser, Pedro R. Lowenstein \& Maria G. Castro
}

To cite this article: Maria B. Garcia-Fabiani, Maria Ventosa, Andrea Comba, Marianela Candolfi, Alejandro J. Nicola Candia, Mahmoud Alghamri, Padma Kadiyala, Stephen Carney, Syed M. Faisal, Anna Schwendeman, James J. Moon, Lindsay Scheetz, Joerg Lahann, Ava Mauser, Pedro R. Lowenstein \& Maria G. Castro (2020): Immunotherapy for gliomas: shedding light on progress in preclinical and clinical development, Expert Opinion on Investigational Drugs, DOI: 10.1080/13543784.2020.1768528

To link to this article: https://doi.org/10.1080/13543784.2020.1768528

Accepted author version posted online: 13

May 2020.

Submit your article to this journal 저

Q View related articles ¿

View Crossmark data $[\pi$ 
Publisher: Taylor \& Francis \& Informa UK Limited, trading as Taylor \& Francis Group

Journal: Expert Opinion on Investigational Drugs

DOI: $10.1080 / 13543784.2020 .1768528$

\section{Immunotherapy for gliomas: shedding light on progress in}

\section{preclinical and clinical development}

Maria B. Garcia-Fabiani ${ }^{1,2}$, Maria Ventosa ${ }^{1,2}$, Andrea Comba ${ }^{1,2}$, Marianela Candolfi ${ }^{3}$, Alejandro J. Nicola Candia ${ }^{3}$, Mahmoud Alghamri ${ }^{1,2}$, Padma Kadiyala ${ }^{1,2}$, Stephen Carney ${ }^{1,4}$, Syed M. Faisal ${ }^{1,2}$, Anna Schwendeman ${ }^{5,6}$, James J. Moon ${ }^{5,6,7}$, Lindsay Scheetz ${ }^{5,6}$, Joerg Lahann, ${ }^{6,8}$, Ava Mauser ${ }^{6,8}$, Pedro R. Lowenstein ${ }^{1,2,6}$, and Maria G. Castro ${ }^{1,2,6}$.

1. Department of Neurosurgery, University of Michigan Medical School, Ann Arbor, MI, USA.

2. Department of Cell and Developmental Biology, University of Michigan Medical School, Ann Arbor, MI, USA.

3. Instituto de Investigaciones Biomédicas (INBIOMED, UBA-CONICET), Facultad de Medicina, Universidad de Buenos Aires, Buenos Aires, Argentina.

4. Cancer Biology Graduate Program, University of Michigan Medical School, Ann Arbor, MI, USA.

5. Department of Pharmaceutical Sciences, University of Michigan, Ann Arbor, MI, USA.

6. Biointerfaces Institute, University of Michigan, Ann Arbor, MI, USA.

7. Department of Biomedical Engineering, University of Michigan, Ann Arbor, MI, USA.

8. Department of Chemical Engineering, University of Michigan, Ann Arbor, MI, USA. 


\title{
Corresponding authors:
}

Maria G. Castro: mariacas@med.umich.edu;

Pedro R. Lowenstein: pedrol@,med.umich.edu.

\begin{abstract}
Introduction: Gliomas are infiltrating brain tumors associated with high morbidity and mortality. Current standard of care includes radiation, chemotherapy and surgical resection. Today, survival rates for malignant glioma patients remain dismal and unchanged for decades. The glioma microenvironment is highly immunosuppressive and consequently this has motivated the development of immunotherapies for counteracting this condition, enabling the immune cells within the tumor microenvironment to react against this tumor.
\end{abstract}

Areas covered: The authors discuss immunotherapeutic strategies for glioma in phase-I/II clinical trials and illuminate their mechanisms of action, limitations and key challenges. They also examine promising approaches under preclinical development.

Expert opinion: In the last decade there has been an expansion in immune-mediated anti-cancer therapies. In the glioma field, sophisticated strategies have been successfully implemented in preclinical models. Unfortunately, clinical trials have not yet yielded consistent results for glioma patients. This could be attributed to our limited understanding of the complex immune cell infiltration and its interaction with the tumor cells, the selected time for treatment, the combination with other therapies and the route of administration of the agent. Applying these modalities to treat malignant glioma is challenging, but many new alternatives are emerging to by-pass these hurdles.

\section{Keywords}


Antibody, CAR T-cell, checkpoint inhibitor, dendritic cells, glioma, immunosuppression, immunotherapy, nanoparticles, vaccines, virus. 


\section{Article Highlights}

- Malignant gliomas or HGG are the most frequent tumors of the central nervous system. Even though there has been advances in their diagnosis and treatment strategies, HGG have dismal prognosis and currently remain incurable.

- It has been demonstrated that HGG display an immunosuppressive tumor microenvironment, involving the recruitment of immunomodulatory cells and the secretion of immunomodulatory cytokines.

- In the last years, there has been an expansion in the immunotherapeutic strategies designed to treat different types of cancers, and many of these are currently approved to be used in the clinic due to their significant improvement in patient survival.

- Treating glioma with an immunotherapeutic approach can be challenging due to their anatomic location, the intrinsic immunosuppressive microenvironment, and the tumor heterogeneity. However, several therapies under pre-clinical and clinical study were developed to beat these hurdles. Also, the development of new alternatives for drug delivery, such as nanoparticles, have yielded encouraging results in preclinical models.

- The development of immunotherapies against glioma is promising since pre-clinical studies in diverse immunotherapies demonstrated encouraging biological effects. However, favorable and long-lasting clinical responses remain to be seen. 


\section{1- INTRODUCTION}

Gliomas are histologically highly heterogeneous tumors and malignant glioma represent the most frequent tumor of the central nervous system (CNS) $[1,2]$. Their incidence in the USA is 6 cases per 100,000 individuals/year [1]. Taking into account both genetic alterations and epigenetic modifications, gliomas are classified integrating histological and molecular parameters to provide more accurate prognosis and treatment strategies [3]. The phenotypic-genotypic diagnostic combination criteria include histological features and genetic alterations analysis, which are considered along with clinical findings and radiological characteristics [3]. Tumor grading is used as a prognostic factor to predict response to therapy [3, 4]. Overall, grade I and II are considered "nonmalignant" or low grade gliomas (LGG), whereas grade III and IV are considered "malignant" or high grade gliomas (HGG), with worst prognosis $[1,3,5]$.

Among gliomas, diffuse infiltrating gliomas represent the most prevalent tumors. The most relevant molecular characteristics studied are $I D H$ mutation, chromosome $1 \mathrm{p} / 19 \mathrm{q}$ deletion, histone mutations and other genetic parameters such as ATRX loss, TP53 and TERT mutations, as well as DNA methylation levels [3, 4]. This group of gliomas includes diffuse astrocytomas (grade II), oligodendrogliomas (grade II/III), anaplastic astrocytomas (grade III), and glioblastomas (GBM) (grade IV) [3].

GBMs are highly infiltrative and the most frequent HGG in adults (median onset 62 years old). The primary tumors are characterized by astrocytic differentiation, nuclear atypia, high mitotic rate, microvascular proliferation and necrosis. They predominate in males and the median survival (MS) is 15-18 months post-diagnosis. They exhibit WT IDH and common mutations as TERT promoter mutation, EGFR amplification, CDKN2A deletion, TP53 loss of function mutation, PTEN mutation, and RTK pathways amplification $[6,7]$. 
In the pediatric context, malignant gliomas seem similar histologically to adult disease. However, at the molecular level they are very different from the adult gliomas [8]. They are classified as pediatric anaplastic astrocytoma (grade III), GBM (grade IV) or diffuse midline glioma (DMG), which includes diffuse intrinsic pontine glioma (DIPG) [9]. Pediatric gliomas hold specific mutations associated with certain anatomic locations. For instance: H3F3AK27M is found in midline locations in DMG and H3F3AG34R/V in cerebral hemispheres $[10,11]$.

The current standard of care (SOC) for the treatment of primary malignant gliomas consists in maximal safe surgical resection, followed by concomitant external beam radiation and chemotherapy with Temozolomide (TMZ) during 6 weeks and then TMZ as adjuvant chemotherapy for six cycles of $150-200 \mathrm{mg} / \mathrm{m}^{2} /$ day for the first 5 days of a 28 -day cycle [12]. In some institutions, the adjuvant therapy has been extended to 12-15 months [13-17]. For LGG, the best SOC remains under revision, but current treatment also involves surgery, beam radiation and chemotherapy (which could include TMZ or a combination of procarbazine, CCNU, and vincristine) [18]. In spite of advances in diagnostic and therapeutic modalities, recurrence is almost universal for GBM. In addition, malignant transformation and recurrence for LGG is also commonly seen in the clinic [19-22].

Although the new phenotypic-molecular integrated diagnosis represents a remarkable advance for glioma's diagnosis, several challenges and limitations remain when considering treatment efficiency. This is in part evidenced by the high rate of tumor recurrence [23]. These challenges include, but are not limited to, the highly infiltrative nature of malignant glioma, which makes it a difficult tumor to resect; the presence of a blood-brain barrier (BBB), which affects drug penetration into the brain; and the intrinsically complex biology of this tumor, meaning that a proposed SOC might not be suitable in all cases [24]. 
Another salient challenge in glioma therapeutics is due to the presence of a highly immunosuppressive tumor microenvironment (TME) [25]. Thus, the implementation of therapies aimed to counteract immunosuppression are promising avenues for glioma treatment [26, 27]. Several studies using diverse immunotherapeutic strategies are in progress. Pre-clinical studies in immunotherapies demonstrated encouraging biological effects, but favorable clinical responses remain to be realized [27-29].

In this review we will discuss novel immunotherapies targeting the glioma TME and the efforts being directed to revert glioma-mediated immunosuppressive mechanisms. We will review immune therapeutic strategies currently being implemented from preclinical studies to Phase-II clinical trials (CTs). We will also discuss their mechanisms of action, their responsiveness or mechanisms leading to treatment resistance, their limitations and future challenges. This review includes, but is not limited to, cancer vaccines, immune checkpoint inhibitors, adoptive cellular therapy, viral therapy and combinational therapies.

\section{2- CNS AND GLIOMA IMMUNE MICROENVIRONMENT}

The notion that the CNS is an "immune privileged" site was adopted after the findings that foreign tissue grafts implanted in the brain parenchyma were not rejected [30-32]. The efferent and afferent arms of the immune system were thought to be abrogated by the BBB and the lack of classical draining lymphatics, respectively [33]. However, evidence demonstrating foreign tissue rejection in the brain implanted in proximity to the ventricles and the draining of CNS antigens into the cervical lymph nodes challenged this view [32-36]. Today, experimental findings showed that the immune privilege of the CNS is not absolute, but rather relative to other organs and to the presence or absence of neuroinflammation. The particular interactions between the immune system and the CNS are related to the CNS anatomy and its compartmentalization, namely: the CNS parenchyma; the 
ventricles containing cerebrospinal fluid; and the meninges [37]. It has been observed that the innate and adaptive immune response mounted in the ventricles and meninges is similar to the response in other organs [37]. Thus, the immune privilege should be associated to the brain parenchyma specifically and the distinctive features of the afferent and efferent arms involved in the neuroimmune-communication.

\section{2-1- Afferent arm in the CNS-immune system interaction}

The afferent arm of the immune system refers to antigen presentation to T-cells, resulting in their proliferation and activation. In general, this is achieved in the draining lymph nodes, by the drainage of antigen-presenting cells (APC) bearing the antigen from the immune-compromised site or by the transport of the soluble antigen to the lymph node. In the absence of inflammation, there is a paucity of dendritic cells (DCs) in the brain parenchyma and, although the presence of resident macrophages, they rarely migrate to the lymph node to act as APC [33, 37]. However, brain parenchyma has soluble antigen drainage along the walls of cerebral capillaries and arteries to cervical lymph nodes [33, 37]. This perivascular pathway is probably too narrow to allow the migration of immune cells from the brain parenchyma, which may be the principal factor involved in the immune privilege of the CNS. In contrast, the direct drainage of cerebrospinal fluid to deep cervical lymph nodes allows the trafficking of T-cells, monocytes and DCs, which could explain in the immunological competence of the compartments surrounding the brain [33]. In summary, the afferent arm of the immune system in the brain lacks the classical cellular pathway, but it relies on the soluble antigen trafficking pathway.

\section{2-2- Efferent arm in the CNS-immune system interaction}

Although the specificities for T-cell trafficking pathway into the brain parenchyma remain to be elucidated, activated T-cells can cross the $\mathrm{BBB}[33,38]$. Within the brain, T-cells will face diverse challenges before they can mediate the immune response, such as death by apoptosis, the presence of immunomodulatory soluble factors or the difficulties associated to antigen recognition due to low 
MHC expression [33, 37]. However, the secretion of IFN $\gamma$ and TNF $\alpha$ by pre-activated T-cells can induce MHC expression in CNS residing cells, which would act as APCs [38]. When antigen recognition occurs by the T-cells, the release of pro-inflammatory molecules triggers changes in the BBB allowing the recruitment of additional immune cells into the brain. Once inflammation is established, the CNS immune privilege state switches into an inflammatory environment, resulting in increased BBB permeability, DC penetration and increased antigen trafficking into the lymph nodes $[37,38]$.

\section{2-3- Glioma immune tumor microenvironment}

Although these data show the active interaction of the immune system with the CNS, multiple clinical trials in immunotherapy have failed to show benefits in glioma patients. One of the main reasons is related to the immunosuppressive TME that halt effective anti-glioma immune response.

Glioma TME is characterized by tissue hypoxia provided by an inappropriate increased vascularity, irregular blood flow and high oxygen consumption. Tissue hypoxia induces activation of regulatory T-cells (Tregs) and upregulation of vascular endothelial growth factor (VEGF), to promote an immunosuppressive environment [39-41]. Glioma cells also secrete immunosuppressive factors such as interleukin-6, interleukin-10, TGF- $\beta$, and prostaglandin-E [42-45]. These factors collectively inhibit both the innate and adaptive immune systems by suppressing NK activity and T-cell activation and proliferation, inducing T-cell apoptosis, downregulating of MHC expression, and skewing tumorassociated macrophages towards an M2 (immunosuppressive) phenotype [46-48].

Myeloid cells represent the main immune cell that infiltrates glioma. We have shown that myeloidderived suppressor cells are major immunosuppressive cells in glioma microenvironment $[28,49,50]$. Also, the number of neutrophils and their activation status correlates with glioma grade and represents a negative prognostic parameter [51]. Moreover, glioma associated macrophages and 
microglia can constitute a significant proportion (around 30\%) of the tumor mass [52-54]. They are recruited by a number of chemokines, including CCL2 and CX3CL1 [55-57].

Within the lymphoid cells, NK cells are the main effector cells mediating antitumor responses in glioma [58], albeit they represent a minor component in the GBM TME (about 2\% of immuneinfiltrating cells). We showed that NK cells can mediate an anti-glioma immune response which is suppressed by gal-1 expression in glioma cells [59]. Tregs are also found in the GBM parenchyma, which have a potent immunosuppressive capacity against anti-glioma T-cells [60]. They can be recruited by GBM secreted factors including CCL22, CCL2 or indoleamine 2,3-dioxygenase 1 (IDO1) [61-63].

In conclusion, GBM TME is enriched with immunosuppressive factors that prevent effective antitumor immunotherapy. Therefore, counteracting glioma-mediated immune suppression is a prerequisite for the development of new and more effective immunotherapies for this devastating disease.

\section{3- CURRENT (ACTIVE) PHASE-I/II CLINICAL TRIALS WITH IMMUNOTHERAPEUTIC APPROACH}

This review was structured taking into account the principal immunotherapeutic approaches against glioma that are currently under Phase-I/II clinical trials (Table 1). We included the clinical trials that were found at clinicaltrials.gov using the key words: "Condition or disease: glioma"; "Study type: interventional studies (clinical trials)"; "Status: Recruitment: Not yet recruiting; Active, not recruiting; Recruiting"; "Phase: Phase 1; Phase 2". For "Other terms" we used the following words: "immune", "vaccines", "CART", “dendritic cell”, “antibody", "virus", "PD1", "PDL1” and "CTLA4". Table 1 was updated in March 2020 and includes all the clinical trials found under those key words. Trials 
were organized in 8 major categories: Immunosuppressive checkpoint inhibitors; Tumor associated antigens/Peptide Vaccines; Dendritic cell (DC) vaccines; Oncolytic virus; Immune Stimulatory Gene therapy; CAR T-cells; Antibody delivery; and Other immunotherapies. The therapies involving antibodies against immunosuppressive checkpoints were distinguished from "Antibody delivery" due to the large amount of clinical trials studying these agents. Finally, we have included a section dedicated to Nanotechnologies to highlight the advantages of this new method for the delivery of immune therapeutics.

\section{1- IMMUNOSUPPRESSIVE CHECKPOINT INHIBITORS}

The immune checkpoints are inhibitory surface proteins or receptors that trigger signals to maintain the homeostasis of the immune system and the tolerance to self-antigens. These signals regulate the durability of the immune response by limiting or inhibiting T-cell activation or by inducing T-cell exhaustion [64-66]. There are two main proteins or receptors extensively studied against which there are currently approved antibodies to be used in the clinical setting for different cancers: the programmed cell death (PD-1) and its ligand PD-L1, and the cytotoxic T-lymphocyte-associated antigen-4 (CTLA-4) $[65,67,68]$. These two pathways are non-redundant and differ spatially and temporally: whilst CTLA-4 signaling occurs in the lymph node during early T-cell activation, PD1/PD-L1 signaling occurs in effector sites on upon T-cell activation through the T-cell receptor (TCR) $[64,65,69]$. The continuous PD-1/PD-L1 interaction and its effect on T-cells represents an immune adaptation that prevents auto-immune reactions due to chronic TCR stimulation. However, this pathway can be hijacked by tumor cells expressing PD-L1 as a mechanism of immune evasion, inhibiting anti-tumor T-cell mediated immune response $[69,70]$.

The goal of inhibiting the checkpoint pathways is to "release the brakes" of the immune system to enhance an anti-tumor immunity (Figure 1). PD-L1 expression on glioma cells and microglia has been 
observed in $38 \%$ of newly diagnosed GBM and its expression is upregulated when compared to LGG $[68,71,72]$. Currently, there are 39 Phase-I/II clinical trials testing the effectiveness of immune checkpoint inhibition in different types of glioma. The great majority of these are studying the effect of monoclonal antibodies targeting PD-1 (Nivolumab, Pembrolizumab or Cemiplimab) or PD-L1 (Durvalumab, Avelumab or Atezolizumab) used in combination with SOC therapies (NCT02530502, NCT02968940, NCT03743662, amongst others) (Table 1). Also, combinational approaches targeting both immune checkpoints are being assessed, in which SOC plus PD-1/PD-L1 in combination with CTLA-4 (Tremelimumab or Ipilimumab) blockade is being tested (NCT02311920, NCT02794883, NCT04145115 and NCT03233152) (Table 1). Moreover, combinational approaches targeting other checkpoint proteins are under evaluation, such as the use of an anti-PD-1 antibody (Nivolumab) plus an antibody against lymphocyte activation gene-3 (LAG-3) (Relatlimab) (NCT02658981) or an antibody against T-cell immunoglobulin and mucin domain-3 (TIM-3) (MBG453) (NCT03961971), other T-cell inhibiting receptors related to T-cell exhaustion, or the use of an anti-PD-1 antibody (Nivolumab) plus an inhibitor of IDO1 (BMS-986205) [73] (NCT04047706). In addition, there are six Phase-I/II clinical trial assessing the effectiveness of combining anti-PD-1 plus VEGF inhibition (NCT03743662, NCT02336165, NCT03890952, NCT03452579, NCT03722342 and NCT03797326), which is currently used in the clinical setting for recurrent GBM (rGBM) (Bevacizumab) (Table 1) [74].

Since the identification of the checkpoint proteins as possible anti-cancer targets, many preclinical studies provided promising results for the treatment of malignant glioma [26, 75-79]. Unfortunately, the use of Nivolumab has not shown an improved survival in patients suffering of rGBM compared to the treatment with Bevacizumab or in combination with an anti-CTLA-4 antibody (Ipilimumab) [80, 81], so today these approaches are being tested in combination with current SOC or other immuno- 
stimulatory strategies, in different clinical settings [82]. The latest preclinical studies employing checkpoint inhibitors for GBM models tested the effectiveness of combined therapies such as, the use of anti-PD-1 plus an antibody against T-cell immunoreceptor with Ig and ITIM domains (TIGIT), another checkpoint inhibitory molecule [83], or the innovative triple-approach of inhibiting PD-1, stimulating OX40 receptor, while stimulating the immune system by whole tumor yaccination [84]. Furthermore, our lab demonstrated that the administration of anti-PD-L1 or anti-CTLA-4 antibodies with TK/Flt3L gene therapy (see Immune Stimulatory Gene Therapy section) improved MS and increased the number of long-term survivors in a GBM mouse model [26].

\section{2- TUMOR ASSOCIATED ANTIGENS/PEPTIDE VACCINES}

Peptide vaccines are short peptides composed by an MHCI or MHCII epitope capable of triggering a tumor-specific immune response [85]. These peptides are based on tumor-associated antigens (TAA) or tumor-specific antigens (TSA). For instance, in a Phase-I trial, tumor cells obtained from surgical resection of malignant gliomas were treated with insulin-like growth factor receptor-1 antisense oligodeoxynucleotide (IGF-1R/AS ODN) to induce tumor cell apoptosis, and were then subcutaneously injected in the patient in combination with a slow diffusion chamber [86] to induce an immune response against the specific epitopes (NCT02507583) (Table 1).

Usually, single peptide vaccines are insufficient to yield antitumor efficacy due to the heterogeneity of antigen expression in GBM, leading to the loss of antigenic variants [87]. To overcome this, patients with rGBM are being treated with a multi-peptide vaccine composed of the epitopes of epidermal growth factor receptor variant III (EGFRvIII), interleukin-13 receptor alpha-2 (IL13Ralpha2), ephrin type A receptor 2 (EphA2), human epidermal growth factor receptor-2 (HER2/neu) and YKL-40 peptides [88-92] in combination with TLR3 agonist poly-ICLC and 
VEGF-blocking antibody Bevacizumab in a Phase-II trial (NCT02754362) (Table 1). Moreover, advances in peptidomics have led to the development of more specific peptides for personalized therapy [93]. Neoantigens could derive from genomic alterations like fusion of genes, deletion or insertion, frame-shift mutations, single-nucleotide variants and structural variants [94, 95] specific for a particular tumor type. Currently, there are clinical trials for vaccines targeting the tumorspecific neo-antigen mutant IDH1 (IDH1R132H) using the peptide PIPIDH1M [96] in combination with GM-CSF, Montanide ISA 51 (oil-based adjuvant) and TMZ (NCT02193347) or using AMPLIFY-NEOVAC with anti-PD-L1 antibody Avelumab (NCT03893903) (Table 1) (PIPIDH1M and AMPLIFY-NEOVAC are both IDH1R132H-based peptide vaccines). In a clinical trial of newly diagnosed DIPG and other gliomas, 29 patients were treated with H3.3K27M epitope K27M (DIPG common TSA) vaccine [97] combined with tetanus/diphtheria toxoid and the TLR3 agonist polyICLC (NCT02960230) (results are pending). A multiple-epitope vaccine (NeoVax) uses personalized neo-antigens in the context of multiple HLA alleles combined with SOC [98]. This strategy was tested in a Phase-I/Ib study for patients with newly diagnosed GBM, showing an increase in the number of circulating neo-antigen-specific CD4+ and CD8+ T-cells [98]. Although this treatment leads to an increase in the infiltration of T-cells in the tumor, these cells exhibit an exhausted phenotype [98]. To overcome this issue, in a new study 46 participants are treated with NeoVax combined with SOC, and the anti-PD-1 antibody Pembrolizumab (NCT02287428) (Table 1). In addition to immunological checkpoint blockade [99, 100], peptide vaccines have been combined with other immune-stimulant strategies, such as agonistic antibody against co-stimulatory immune-checkpoint molecule CD27 Varlilumab [101], or CD4 and CD8 response inductor Montanide ISA 51 [102]. 
In the ongoing trials, peptide vaccines are administered in combination with SOC treatments. For instance, in a Phase-II trial, newly diagnosed GBM patients are being treated with SurVaxM peptide vaccine (SVN53-67/M57-KLH), that contains a synthetic peptide derived from the TAA survivin [103], in combination with Montanide ISA 51, GM-CSF (Sargramostin) [104] and TMZ (NCT02455557) (Table 1).

\section{3- DENDRITIC CELL VACCINES}

Dendritic cells (DC) are APCs, which have the capacity to recognize pathogens, process them and present the antigens in the context of MHCI and II molecules in the lymph nodes to activate naïve and memory T-cells or NK T-cells [105]. DCs also regulate the immune response through the secretion of pro or anti-inflammatory cytokines [106]. Currently, DC vaccines (DCV) are generated by ex vivo differentiation of DC from autologous monocytes with a cocktail of cytokines [107]. There are a number of factors that affect the efficacy of the DCV: optimal maturation protocol, tumor antigen loading, the adjuvant used, route and frequency of vaccination, and the combination with other therapies [107-109]. Current trials are using different combinations to select the one that triggers the best immune response and overall survival (OS) with low toxicity (Figure 2). Usually, the tumor is lysed after surgical resection to obtain enough TAA to pulse DCs [110] (or to directly inject them as a vaccine to trigger a specific immune response against the tumor epitopes [111]) (NCT01635283) (Table 1). To overcome tumor heterogeneity and to use different antigens, total tumor RNA (TT-RNA) has been used to pulse DCs [112]. In this way, tumor autologous antigen mRNA can be generated to transfect DCs and promote the presentation of TSA [113]. Transfection of mRNA that expresses the human Cytomegalovirus (CMV) matrix protein pp65, which was shown to be highly expressed in GBM by several groups [114-116], fused with the lysosome-associated membrane protein (LAMP), improved presentation in the context of the MHCII molecule. In a small 
trial, patients were treated with CMV-pp65-LAMP mRNA-loaded DCs in combination with GM-CSF and TMZ administration, which increased progression free survival (PFS) and OS, and upregulated IFN $\gamma$ levels [117] (NCT00639639). In spite of these encouraging results, the presence of CMV DNA or proteins in glioma has been challenged recently, and its relevance as an oncomodulator is under reconsideration [118-120].

Other strategies use different sources to obtain tumor lysate and in an ongoing trial 10 DIPG patients were treated with autologous DCs that were pulsed with an allogeneic DIPG cell line (NCT02840123) [121] (Table 1).

Topical or intramuscular administration of TLR7/8 agonists Imiquimod (R837) or Resiquimod (R848) as adjuvants has shown an augmented immune response based on the presence of tumorspecific CD8+ T-cells [122-124] (NCT01808820; NCT01204684) (Table 1). In current trials, patients are treated with these adjuvants before and after receiving the DCV. The use of TLR3 agonist polyICLC as DCV adjuvant, with promising results in pancreatic cancer [125], is being tested in CNS tumor patients (NCT01204684) (Table 1). However, new studies suggest that TLR adjuvants could exert a pro-tumoral effect depending on the tumor and its TLR receptor repertoire [126]. On the other hand, it was observed that pre-treatment of the patients with tetanus/diphtheria toxoid greatly increase DCs migration to the lymph nodes in the context of host CCL3, improving tumor antigen presentation [127].

Two active trials use personalized mRNA pulsed DCV monotherapy in patients with newly diagnosed (PerCellVac) or recurrent (PerCellVac2) GBM to asses PFS, OS and antitumor antigen specific T-cell response (NCT02709616, NCT02808364) (Table 1).

Over the past 20 years, several clinical trials employed DCV for treatment of HGG [128]. In multiple cases, a significant increase in the PFS and OS was observed, whereas in other studies, no differences 
compared to the historical controls were reported [128]. DCV therapy is currently combined with SOC for both newly diagnosed and rGBM. It has been observed that the time of administration of TMZ and DCV affects the outcome of the immune-stimulatory therapy [129]. TMZ in high doses induces lymphodepletion and evidence shows that while TMZ administration could enhance DCtherapy when co-administered with DCV [130, 131], TMZ administration post DCV application may hamper DC-induced anti-tumor immunity [129]. Lymphodepletion was induced prior vaccine administration in the BRAVO study for brain stem gliomas (NCT03396575). This therapy involves the reinjection of T-cells that are previously co-cultured with TT-RNA pulsed-DCs to "educate", expand and activate lymphocytes, plus TT-RNA DCV combined with tetanus/diphtheria toxoid and GM-CSF adjuvance [132]. Finally, blockade of VEGF with Bevacizumab [133] or immunosuppressive molecules, such as PD-1 with Nivolumab [134], are used in combination with SOC and DCV in ongoing clinical trials (NCT02010606, NCT02529072) (Table 1).

\section{4- ONCOLYTIC VIRUS}

Oncolytic viral therapy combines tumor-specific cell lysis with immune stimulation. These viruses selectively replicate in tumor cells inducing killing and exposing cancer cell antigens to immune effector cells for activation [135-137]. In addition, oncolytic viruses (OV) have been genetically engineered to express therapeutic transgenes to further boost antitumor immunity [138].

Among the wide range of studied viruses, only one wild-type virus, the reovirus, is under clinical investigation. Marketed as Reolysin, oncolytic reovirus has been tested for many cancers although with small benefits reported in GBM patients (NCT00528684) [139-141]. A dose escalation PhaseI trial is currently studying the combination of intravenously (i.v.) administrated Reolysin and subcutaneous administrated Sargramostim (GM-CSF), in patients with recurrent HGG (NCT02444546) (Table 1). 
Herpes virus simplex 1 (HSV-1) was the first genetically engineered OV to treat brain tumors [142] and there are currently four types in clinical trial. G207 was well tolerated without evidence of encephalitis in three Phase-I studies in adults with rGBM and induced antitumor activity [143-145]. Currently, two ongoing Phase-I trials are testing the intratumoral infusion of G207 alone or in combination with radiation in pediatric patients (NCT03911388, NCT02457845) (Table 1). A second generation oHSV G207-based that expresses human IL-12 (M032; NCT02062827) (Table 1) is being examined in a Phase-I trial for patients with recurrent or progressive glioma. Two more types of oHSV are in clinical trials for rGBM: rQNestin34.5v.2 (NCT03152318), engineered to improve tumor cell specific targeting [146], and C134 (NCT03657576), engineered to enhance viral replication without increasing neurovirulence [147] (Table 1).

The replication-competent adenovirus DNX-240, marketed as Tasadenoturev, was generated to restrict the viral replication to cells with retinoblastoma pathway deficiency [148, 149]. DNX-240 was first studied in a double-arm Phase-I trial to treat patients with rGBM, reporting $20 \%$ of patients surviving more than 3 years and 3 complete responders (NCT00805376) [150]. In a second study, addition of IFN- $\gamma$ expression did not improve patient's survival compared to the monotherapy (TARGET-I; NCT02197169). However, the combination of intratumoral DNX-2401 with Pembrolizumab, is currently under evaluation in a Phase-II trial for rGBM (CAPTIVE, NCT02798406) (Table 1). Further, a Phase-I is testing the stereotactic injection of a DNX-2401based adenovirus expressing OX40 ligand in patients with rGBM (DNX-2440, NCT03714334). Another strategy involves the delivery of neural stem cells transduced with OV Ad5-DNX-2041 or NSC-CRAd-Survivin-pk7 in patients with rGBM and newly diagnosed malignant gliomas respectively (NCT03896568, NCT03072134) (Table 1). A Phase-I trial has expanded the evaluation of DNX-2204 in pediatric patients with DIPG (NCT03178032) (Table 1). 
Several studies have shown the therapeutic potential of PVSRIPO, a live attenuated poliovirus type-1 [151]. PVSRIPO tropism towards CD155, highly expressed in tumor cells and APCs, enables infected tumor cell cytotoxicity and stimulation of an inflammatory response [152-154]. Currently a Phase-II, randomized trial is testing PVSRIPO alone or in combination with single-cycle lomustine (NCT02986178) and a Phase-Ib/II trial is studying PVSRIPO in combination with the anti-PDL1 antibody Atezolizumab (NCT03973879), both in patients with rGBM (Table 1). Finally, a third PVSRIPO-based therapy is ongoing for pediatric patients with rGBM (NCT03043391) (Table 1). Collectively, the successful accrual of these trials will demonstrate whether improved safety, tumor specificity and efficacy of OVs alone or in combination with other therapies can be translated into the clinic arena.

\section{5- IMMUNE STIMULATORY GENE THERAPY}

Immune stimulatory gene therapy (GT) enables the local administration of non-replicative recombinant viral vectors expressing immune activators to enhance the antitumor immune response.

Many studies have evaluated the efficacy of local overexpression of pro-inflammatory cytokines such as IL-12, a cytokine endogenously produced by APCs that plays a critical role in the adaptive type 1 cell-mediated immunity [155]. Despite encouraging results in murine models, Phase-I studies of systemic administration of recombinant human IL-12 in patients with advanced malignancies were discontinued due to the poor tolerability $[156,157]$. Therefore, a novel approach was developed using adenoviral vectors expressing a regulated human IL-12. This system is controlled through the RheoSwitch Therapeutic System ${ }^{\circledR}$ gene switch (Ad-RTS-hIL-12) under regulation of an oral activator ligand, veledimexin (VDX) [158]. In an open label Phase-I trial, the intratumoral delivery of Ad-RTS-hIL-12 was reported to stimulate tumor-specific T-cell responses with a reduced systemic toxicity in patients with rGBM (NCT02026271) (Table 1). At 12 months, the survival rates of 
patients who received the preferred dosing regimen of hIL-12 with VDX and low-dose steroids, compared favorably to historical controls [159]. However, the apparent deleterious impact of the corticosteroids, when dosed with VDX, expanded the trial to a Phase-I sub-study that is evaluating this controlled hIL-12 platform as a monotherapy (NCT03679754) (Table 1). In a separate Phase-I trial, the Ad-RTS-Hil-12/VDX system is being tested in combination with Nivolumab (NCT03636477) (Table 1). Further, a Phase-II trial will study the inducible hIL-12 in combination with PD-1 antibody Libtayo (Cemiplimab-rwlc: NCT04006119) (Table 1). A Phase-I trial has expanded the evaluation of the Ad-RTS-Hil-12/VDX therapy in pediatric patients with DIPG (NCT03330197) (Table 1).

On another approach, the local administration within the resection cavity of recombinant adenoviral vectors encoding the Fms-like tyrosine kinase 3 ligand (Ad-Flt3L) was shown by our laboratory to recruit DCs within the brain parenchyma, thus improving the brain's immune surveillance and triggering an anti-GBM immune response [160-162]. To enhance the antitumor immune response, this immune-stimulatory approach was combined with adenovirus expressing a conditional cytotoxic herpes simplex type 1 thymidine kinase (Ad-TK) in the presence of the prodrug Ganciclovir (GCV) [163-166]. Preclinical results proved that the Ad-Flt3L/Ad-TK (+GCV) treatment is safe and showed an increase in the survival of tumor-bearing animals, inducing long-term immunological memory through a HMGB1-mediated activation of the TLR2 signaling [163, 164, 167-172]. Results from a dose escalation safety study in patients with primary GBM are expected by the end of 2020 (NCT01811992) (Table 1). Also, early in 2021, this approach is going to be tested in combination with anti-PD-1 immune checkpoint inhibition therapy.

The Ad-TK mediated suicide GT has been also tested in combination with SOC [173]. However, encouraging results from a multi-institutional Phase-II study (NCT00589875) contrasted with 
negative results from a Phase-III randomized open-label trial with a similar approach (NCT00870181) [173, 174]. A Phase-I trial is currently evaluating the intratumoral delivery of AdTK and oral administration of the prodrug Valacyclovir coupled with SOC and the checkpoint inhibitor Nivolumab in newly diagnosed patients with HGG (NCT03576612).

\section{6- CAR T-CELLS}

The adoptive cellular therapy of chimeric antigen receptor (CAR) T-cells is based on the reprograming of the patient's cytotoxic T-cells to express recombinant surface molecules that combine the antigenrecognizing variable region of an antibody in tandem with intracellular T-cell signaling domains [175, 176]. CARs are composed of a B-cell receptor derived extracellular antibody single-chain variable fragment, a T-cell receptor (TCR) derived CD3 $\zeta$ domain, and intracellular co-stimulatory fractions $[177,178]$. This structure allows CAR T-cells to target specific antigens independently of HLA expression, downregulation of which is a common strategy of immune evasion by tumors [178]. When the CAR recognizes a tumor associated antigen, it induces T-cell activation, resulting in the tumor lysis via direct cytotoxic T-cell-tumor cell interactions and cytokine release [176].

There are currently two CAR T-cell based therapies approved by the FDA for hematologic malignancies $[179,180]$. However, treating solid tumors, and specially gliomas, with this therapy might be more challenging due to the presence of an immunosuppressive TME $[54,181]$.

Currently, there are 17 clinical trials on Phase-I/II testing the effectiveness of CAR T-cells in glioma. Predominantly, these T-cells were modified to express a CAR to recognize TAA, such as IL-13R $\alpha 2$ (NCT02208362 and NCT04003649), HER2 (NCT03389230, NCT03383978 and NCT03500991) or EGFRvIII (NCT02664363, NCT03726515, NCT03941626, amongst others) (Table 1) [182-184]. In addition to these antigens, today there are Phase-I/II clinical trials evaluating CAR T-cells which target other three TSA: disialoganglioside GD2 for DMG [185], B7-H3 (CD276) for recurrent and refractory 
GBM [186, 187] and EphA2 for malignant gliomas [188, 189]. Amongst these trials, only one is assessing the effect of CAR T-cell with concomitant SOC (NCT04077866), whilst the others are assessing CAR T-cell therapy in refractory and recurrent malignant glioma (Table 1).

While these approaches have shown promising results in preclinical studies [190-195], their translation to the clinical setting has yielded less conclusive outcomes. The available results published for the finished clinical trial evaluating IL-13R $\alpha 2-$, EGFRvIII- or HER2-CAR T-cells in patients with GBM or recurrent/progressive GBM demonstrated the safety and low toxicity of CAR T-cell administration, evidence of cell trafficking into the brain when administered I.V., and transient anti-glioma responses [182, 184, 196-198]. However, no consistent and lasting response has been observed so far for GBM and for other solid tumors in general $[182,199]$.

The clinical development of CAR T-cell therapy for brain tumors has just started and preclinical and clinical data are encouraging in terms of feasibility and safety $[182,199,200]$. Treating brain tumors with CAR T-cell based therapies is challenging because of their anatomic location, the intrinsic immunosuppressive TME, and the tumor heterogeneity [200]. Also, the fact that they are solid tumors is another obstacle for this therapy, since cell trafficking into the tumor is hindered and, unlike hematological malignancies, they usually lack one specific tumor antigen to target [199]. To address these issues, many approaches are being employed. The route of delivery for CAR T-cells is a key factor and, even though i.v. administration was successful in trafficking cells to the brain tumor mass, locoregional administration seems to be a more effective and safer way to deliver them [196, 201204]. To overcome the immunosuppressive environment, there are several strategies being evaluated in the preclinical and clinical setting. One of these is administrating CAR T-cells in combination with checkpoint inhibitors. Currently, there are two Phase-I/II clinical trials studying the combination of CAR T-cells with an antibody against PD-1 (NCT03726515) or with both anti-PD-1 and CTLA-4 
antibodies (NCT04003649) (Table 1). Another strategy in preclinical development is the disruption of PD-1 gene (PDCD1) by CRISPR-Cas9 technology in the CAR T-cells [205]. Moreover, CAR T-cells have been engineered to secrete pro-inflammatory cytokines to stimulate T-cell function and proliferation [206]. Last but not least, tumor heterogeneity is a key aspect to tackle. In preclinical and clinical studies for CAR T-cells against different TAA, it has been observed the relapse of GBMs with no or low expression of that specific antigen, highlighting the importance of considering the heterogeneous antigen expression in this type of tumor to avoid antigen escape [196, 197, 206, 207]. A strategy to address this issue is to use CAR T-cells to target more than one antigen. This could be achieved by administering different mono-specific CAR T-cells, by engineering CAR T-cells expressing CARs specific for different antigens or by the design of CAR molecules targeting more than one antigen [208-210].

\section{7- ANTIBODY DELIVERY}

Antibody delivery is a type of "passive immunotherapy" in which the immune system of the patient is not involved in the initiation of the immune response but rather acts as a consequence of the administration of immune factors, such as cytokines or antibodies. The outcomes of the passive immunotherapies are temporally dependent on the administration of the treatment and usually do not induce immunological memory. Antineoplastic antibody delivery therapy usually relies on the administration of monoclonal antibodies specific for an antigen that would recruit phagocytes and activate the complement system to destroy the tumor cells [211, 212]. Also, they could be used to disrupt a signaling pathway or as a way to deliver localized radiation (radiolabeled antibodies) or a toxic agent $[211,212]$. 
Currently, there are 32 Phase-I/II clinical trial testing monoclonal antibodies with or without current SOC in both recurrent and newly diagnosed malignant gliomas. Sixteen of these trials are studying the efficiency of an anti-VEGF antibody (Bevacizumab), which has already been approved in 2009 by the FDA for its use in rGBM in the USA [213-215], but not in the primary setting since no benefit on the OS was observed in two separate controlled studies [216, 217]. VEGF is a key pro-angiogenic factor that stimulates the proliferation, invasion and migration of endothelial cells [218], is overexpressed by tumor cells in GBM [219] and negatively correlates with prognosis [218, 219]. In spite of the FDA approval of the anti-VEGF therapy, there is no consensus for the SOC for patients at first GBM recurrence and this is why different combinations are currently being tested in clinical trials. The clinical advantage of Bevacizumab is limited if not scarce and its benefit compared to the use of other common therapies is still controversial [213-215]. The use of Bevacizumab in the pediatric population for newly diagnosed HGG was also evaluated, plus SOC. Results indicated no improvement in event free survival and OS after the addition of Bevacizumab to the current SOC [220]. Although clinicians were motivated at the beginning by the superior radiographic response from Bevacizumab trials on rGBM, the lack of OS improvement raised the question if this drug is actually acting as an antineoplastic agent or if it is just normalizing the blood vessel density in the tumor, decreasing the penetration of gadolinium and thus, decreasing the volume of contrast enhancement in magnetic resonance imaging $[211,212]$. Either way, it is still necessary to analyze the results of the ongoing clinical trial using Bevacizumab with different SOC combinations to conclusively determine the usefulness of this antibody therapy.

Another strategy to target HGG is through the use of antibodies against tumor-specific or -associated antigens. The amplification or mutation of EGFR gene is the most frequent genetic alteration in GBM, present in $40-60 \%$ of the tumors [221]. Even though promising results in the preclinical setting [211, 
222-224], today no agent targeting EGFR or EGFRvIII has been approved by the FDA for its use in GBM [221]. Currently, there are 8 Phase-I/II clinical trial testing the use of antibodies against EGFR, EGFRvIII or both for recurrent and newly diagnosed GBM (NCT02540161, NCT02573324, NCT02590263, NCT03620032, NCT02303678, NCT02800486, NCT04160494 and NCT03618667) (Table 1). These trials usually involve the use of anti-EGFR/EGFRvIII therapy plus SOC. The use of these antibodies showed acceptable safety and pharmacokinetic profile in GBM [225], however, in many cases clinical trials have failed to demonstrate the desired results [221]. It is possible that the use of a therapy targeting a single antigen is not ideal in these tumors, as they are highly heterogeneous. Specifically, EGFR and EGFRvIII expression is heterogeneous in GBM and currently its importance as an anti-tumor target is being debated [226]. Other monoclonal antibodies being tested in Phase-I/II clinical trials target other TAA, such as EphA3 or GD2, or are designed to stimulate the immune response by their binding to immune stimulatory domains (NCT03374943 and NCT00445965).

Antibody therapy faces the same challenges that many of the immunotherapies against glioma. One of those is the BBB [227], for which different strategies are under study. For instance, antibodies have been conjugated to cell-penetrating peptides, that facilitate the BBB crossing through the negatively charged membrane of the endothelial cells $[227,228]$ or stem cells have been used for the in vivo antibody production and delivery [227, 229]. Another strategy under preclinical development to improve antibody's efficacy is the use of bispecific antibodies (bsAbs), which recognize two different epitopes. For example, bsAbs targeting Agn-2 and TSPO or Ang-2 and VEGF extended the survival of murine GBM models, while stimulating the immune anti-tumor response [230, 231]. A special type of bsAbs are the BiTEs, bispecific antibodies that link a TSA with a co-stimulatory molecule on a T-cell, establishing immunological synapses [227], such as BiTEs targeting EGRFvIII and the T-cell activation ligand CD3 [232, 233]. 


\section{8- OTHER IMMUNOTHERAPIES}

\section{8-1. IDO1 INHIBITION}

IDO1 induces immunosuppression by tryptophan degradation [234], which eventually leads to T-cell killing and Tregs recruitment [235]. In a healthy human brain, IDO1 expression is negligible [236]. Conversely, it is upregulated in 90\% of GBM [237] and its expression correlates with aggressiveness [238]. Like other inhibitors, IDO1 inhibitors did not show significant antitumor efficacy when administered as a monotherapy. However, today there are clinical trials studying the efficacy of IDO1 inhibition with SOC in different clinical settings (NCT03532295, NCT02502708 and NCT04049669) (Table 1). Also, the efficacy of IDO1 inhibitor (INCB024360) in combination with Nivolumab, Anti-GITR Monoclonal Antibody (MK-4166) and Ipilimumab in patients with rGBM (NCT03707457) is being tested (Table 1). These trials will soon yield valuable information on the safest and most efficacious approaches for the application of this therapy.

\section{8-2. ANGIOGENESIS INHIBITION AND INDUCTION OF IFN $\gamma$}

Pomalidomide is an anti-angiogenic and immunomodulatory compound [239]. Pomalidomide promotes T-cell-mediated antitumor immunity by inhibiting the expression of PD-L1 [240] and by inducing the expression of IFNy and IL-2 [241]. In 2015, a Phase-I clinical trial using Pomalidomide was opened to treat young patients showing recurrent, progressive, or refractory CNS tumors (NCT02415153) (Table 1). Also, another Phase-II trial using Pomalidomide (CC-4047) monotherapy for the treatment of recurrent or progressive primary brain tumors in children and young patients (NCT03257631) was started in 2017 (Table 1).

\section{NANOTECHNOLOGIES}


The therapeutic challenges for GBM associated to the presence of the BBB, which precludes readily permeation of chemotherapeutics into the brain parenchyma [242]; the tumor heterogeneity, which makes targeting single pathways ineffective [7]; and the tumor invasiveness and relapse [19, 243] are being tackled by the development of more efficient delivery methods. Nanoparticles (NPs) are emerging as a promising therapeutic approach to enhance the efficacy of glioma immunotherapy. Formulations based on nanotechnology have been developed to non-invasively deliver immunomodulatory agents to the tumor site [244, 245] while avoiding immunogenicity and offtarget side effects [246-252]. NPs with an optimal size for lymphatic trafficking (10-100nm) facilitate target cellular uptake of the immunomodulatory agent, increase the drug bioavailability at the tumor site while reducing the drug dosing frequency [245]. Biomaterials such as albumin, liposomes, and lipoproteins are utilized to engineer NPs [246-251], which enable the encapsulation of both hydrophilic and hydrophobic therapeutic agents, and protect them from biochemical degradation [246-251].

We have recently demonstrated that local treatment of glioma with sHDL-mimicking nanodiscs containing ApoAI mimetic peptide, phospholipids, immunogenic cell death inducing chemotherapeutic (ICD) agent docetaxel, and adjuvant $\mathrm{CpG}$ oligodeoxynucleotide effectively elicit anti-tumor $\mathrm{T}$ cell activity and induce immunological memory response against tumor relapse [253]. Local drug delivery at the time of surgery allows for the treatment of residual tumor cells in the surgical cavity, prolonging the period to recurrence due to strong anti-glioma immunological memory response prompted by this NP-mediated therapy. Whether sHDL-mimicking nanodiscs loaded with ICD agent and adjuvant $\mathrm{CpG}$ can achieve a survival benefit in the clinic remains to be seen. 
Nanovaccines based on superparamagnetic iron oxide (SPIO) NPs provide another novel approach to induce immunomodulatory anti-glioma response [254]. A preclinical study demonstrated that vaccine formulation containing SPIONPs encapsulated with heat shock protein 70 , which induces anti-tumor immune response, improved antigen loading into the dendritic cells [254]. Treatment of glioma bearing mice with these SPIONPs inhibited glioma growth and elicited robust anti-glioma immune response. These data indicate that NP based vaccines could have a great potential for clinical translation. In addition, our team recently demonstrated that sHDL-mimicking nanodiscs serve as an efficient delivery platform targeted to lymphoid tissues $[248,255,256]$. Using this system, we have shown that neoantigens, which are tumor-specific antigens identified from mutated tumor cells, can be identified from GBM and used in conjunction with nanodiscs to generate potent T-cell responses against GBM (manuscript under review). Specifically, nanodiscs delivering GBM neoantigens combined with anti-PDL1 immune checkpoint blockade resulted in a significant increase in median survival and complete tumor regression in $93 \%$ and $33 \%$ of mice bearing GBM at flank and orthotopic sites, respectively, thus demonstrating a general strategy for personalized cancer immunotherapy [257].

By the modification of the NPs with various coating materials, efficient delivery of molecules can be achieved $[258,259]$. One such modification, tumor-penetrating peptide, iRGD has been shown to facilitate the NP transport and CNS penetration [260-262]. We recently demonstrated that albumin NPs loaded with siRNA against signal and transducer of activation 3 (STAT3) transcription factor (which inhibits immune functions upon activation), and iRGD penetrate the BBB and that, when administered in combination with SOC, extend MS of mice bearing glioma and elicit robust antiglioma immune response [262]. 
Other peptide modifications on nanoplatforms have been explored to minimize off target accumulation and facilitate active targeting or mediate BBB transport. Interleukin 13 (IL-13) receptor, IL-13 R $\alpha 2$, is overexpressed on glioma cells, and has therefore become an attractive receptor target for peptide-modified nanotherapies [263]. This high affinity receptor is an advantageous target due to its decoy-like characteristics without causing downstream signaling activation and its low affinity towards unaffected brain tissue [264, 265]. Madhankumar A.B. et al. demonstrated IL-13-conjugated liposomes showed enhanced efficacy in a subcutaneous mouse model for glioma [263]. Gao H. et al. conjugated IL-13 to NPs which resulted in increased cellular uptake via endocytosis, higher internalization, and improved localization to the tumor site in an orthotopic glioma mouse model [266].

The transferrin receptor (TfR) has been extensively researched as a target for various CNS diseases including gliomas because TfR is overexpressed on brain capillary endothelial cells and glioma cells [267]. It also facilitates transport across the BBB through TfR-mediated transcytosis. Despite exploiting the use of TfR as a target for decades, translation of systems leveraging these findings has been limited [268]. Epidermal growth factor receptor (EGFR), a receptor that is highly expressed in various cancers, is another target that has been of interest for nanotherapies [269]. The seven-peptide (sequenced HAIYPRH, T7), which has greater affinity for TfR, has been used for glioma targeting to deliver siRNA [270], coupled with other targeting ligands to demonstrate increased transport across the BBB and greater tumor penetration [271].

Although targeting strategies through peptide conjugation can improve the delivery of therapeutic agents in NPs, they are still not sufficient to effectively promote drug delivery to brain tumors. Other design approaches have focused on modulating the size, morphology, surface charge, composition, 
$\mathrm{pH}$ and coupling these design parameters to maximize therapeutic efficacy, transport across the BBB, control circulation time, reduce toxicity, and modify the biodistribution.

As multidrug resistance and toxicity become evident challenges in glioma treatment, designing combination therapy delivery systems within nanoparticles is necessary. Combination therapy (CT) is a therapeutic dosing strategy where two or more drugs are combined. The motivation to potentially slow drug resistance, make therapeutic effect stronger via synergism, and maintain a therapeutic effect using lower doses, thus reducing toxicity and off target effects [272]. Effects of CT can be categorized as synergistic, enhancing, antagonistic, or additive. However, without a universal definition of synergism, it has been challenging to evaluate synergism claims and thus has further complicated FDA approval, grants applications, and ultimately advancing CT approaches [273]. Benefits of CT in nanoplatforms include delivering hydrophobic and hydrophilic drugs in one system, controlling release of one agent to sensitize the other, slowing down multidrug resistance, improving therapeutic effects while reducing toxicity, among others [274]. Though combining multiple drugs isotropically mixed throughout a carrier particle can be done to achieve benefits of CT, creating multicompartmental nanoparticles may be advantageous, because it can overcome critical formulation challenges (i.e., incompatible solvent systems, drug interactions), while expanding the design capabilities and maximizing therapeutic outcomes [274]. Leveraging multicompartmental carries can not only incorporate this solubility advantage but facilitate implementing other drugs regardless of their solubility compatibility. Liposomes have been used to incorporate hydrophobic drugs in the lipid envelope and hydrophilic drugs in the lipid envelope to produce a single carrier system. Similarly, bicompartmental nanoparticles can be used to deliver different drugs with independent release kinetics. Figure 3 shows a bicompartmental polymeric nanoparticle composed of polylactide-co-glycolide (PLGA) in one compartment and a mixture of PLGA and 
acetal-modified dextran in the second. In this example, the acetal-modified dextran PLGA compartment was pH-responsive and could thus be used to release irinotecan, a cancer therapeutic, in an acidic $\mathrm{pH}$ microenvironment [275]. Thus, these act as $\mathrm{pH}$ responsive carriers, enabling drug release at optimal $\mathrm{pH}$ conditions.

Another motive of such multicompartmental systems is to tune the pharmacokinetics of each section individually. Although a free drug combination may achieve synergism, the release kinetics of the drugs in the NP must be considered to ensure the ratio that achieved that synergism is maintained at the tumor site. Tuning the release is also a consideration in the delivery of sensitizing agents prior to cytotoxic drugs. Chemosensitizers such as verapamil, elacidar and tariquidar have been used to sensitize doxorubicin and paclitaxel and can be used to overcome MDR [274]. Guo L. et al. synthesized Tumor necrosis factor-related apoptosis-inducing ligand (TRAIL) liposomes (TRAILLP) and doxorubicin-loaded liposomes (DOX-LP). DOX-LP sensitized TRAIL-LPs and therefore improved the therapeutic effect [276].

Among the advantages, NPs can be tailored for drug loading and protection; their surface characteristics (size, shape and surface charge) can be exploited for extending the half-life in circulation, and they can be precisely biofunctionalized with specific targeting ligand for drug accumulation at the tumor site. In summary, NPs are an attractive, less-invasive, drug-delivery carrier for glioma immunotherapeutics, capable of overcoming the current challenges encountered by traditional therapeutic approaches.

\section{CONCLUSION}

Immunotherapy has become a revolution for cancer treatment for its outstanding outcomes in several types of malignancies. Applying these modalities to treat malignant glioma in the clinical setting is 
challenging, as demonstrated by the lack of long-lasting improvements in patient survival. However, it is important to learn from the failures to find the best treatment combination to eradicate these tumors and generate anti-tumor immunological memory. We hope that this review will help neurooncologists, neurosurgeons, the scientific community and the patients to become aware of the diversity of therapies under study in the glioma field and which are the obstacles that we need to tackle.

\section{EXPERT OPINION}

In the last decade, we have experienced an expansion in the immune-based anti-cancer therapy strategies, and many of those innovations have been approved for the treatment of different neoplasms in the clinical setting $[65,184,277]$. In the glioma field, many efforts have been devoted to the development of therapies aimed to harness the immune system potential to direct it against brain tumors and extensive preclinical data investigating different immunotherapeutic modalities yielded encouraging outcomes [27]. It is striking to observe how complex and sophisticated these therapies have become in order to be as specific and powerful as possible. Several Phase-I/II clinical trials have demonstrated safety and feasibility for the administration of immunotherapies in combination with SOC $[71,278]$. Unfortunately, the outcomes of these trials have not yielded consistent results for primary brain tumors, highlighting the need of research models that better depict the human disease [73]. Even though these pitfalls, there are still many other alternatives under development in the preclinical setting and under evaluation in ongoing clinical trials [73, 277].

There are several characteristics intrinsic to brain tumors that make them particularly difficult to target by the immune system. For instance, the presence of the BBB, the immunosuppressive TME, the low mutational burden and the antigen heterogeneity [278]. However, the evidence that patients 
with disorders related to the hyperactivation of the immune response, such as allergies, had a lower risk of suffering glioma [279], evidenced that the immune system plays a role in the development of this disease and that pursuing the objective of directing it to fight brain cancer is a path worth taking. Lately, the use of CAR T-cells for glioma treatment has become an exciting idea in the neurooncology community and many efforts are being put to obtain the best CAR T-cell. For example, an alternative recently presented by Choi BD et al., is the use of CAR T-cells secreting BiTEs. In an elegant study, they used T-cells expressing a CAR specific for EGFRvIII and BiTEs against EGFR. They could confirm that the secretion of EGFR-BiTEs by the EGFRvIII-CAR T-cells avoided antigen escape observed previously with monospecific EGFRvIII-CAR T-cells alone and eliminated the tumors in models of heterogeneous glioma, expressing both EGFRvIII and EGFR [204]. The clinical relevance of CAR T-cells expressing BiTEs still needs to be evaluated.

Undoubtedly, combinational therapies constitute the best approach to treat malignant glioma. Considering the large amount of immune-based therapies developed, the numerous possible targets, the current SOC, and the many possible timings and routes for drug administration, the number of potential combinations has increased exponentially. Several combinatorial approaches are today under study in clinical trials, not only integrating immunotherapies with SOC but also with other immune-stimulant agents. Currently, there is no consensus on which is the best combination or the ideal timing for drug administration. Recently, results from a clinical trial in which Pembrolizumab (anti PD-L1) was administered before or after surgery resection of the tumor demonstrated the importance of the selection of the starting point for the treatment. Patients who received the anti-PDL1 as neoadjuvant (before surgery) lived as twice as long as the patients treated with the same drug as adjuvant (after surgery) and the infiltration of activated T-cells into the tumor was demonstrated in the former group [82]. Also, uncovering the interactions between SOC and new drugs is crucial to 
decide how and when treat a patient and prevent misleading results in clinical trials [71]. For example, while lymphopenia, a common consequence after chemoradiation treatment for malignant glioma, is a disadvantage for the application of cancer vaccines, it could represent a favorable context for the treatment with adoptive cell therapies, such as CAR T-cells or DCV [71]. Thus, it is crucial to keep track of the results of the latest trials studying different treatment variants to improve patient selection, to prevent random testing and to build collaborative guidelines for the treatment of glioma.

Moreover, as drug penetration in the brain is an issue for GBM treatment, different ways of administering these agents are being assessed and, so far, intracranial delivery, though invasive, has demonstrated to be the most efficient in several approaches. However, the development of less invasive methods of administration with brain or tumor homing characteristics has given encouraging results in the pre-clinical setting lately [251]. Nanoparticles have emerged as a new and safe method for the delivery of agents targeting brain tumors and preclinical results are encouraging [253]. For example, nanoparticles injected i.v. composed of albumin, a siRNA against STAT3 and the tumor penetrating peptide iRGD, showed effective brain tumor delivery and a significant survival benefit in an aggressive glioma model [262]. It would be interesting to test the efficacy of these particles for the delivery of immune-stimulatory agents in the clinical setting.

In addition to the progress made in the field of immunotherapeutic approaches, more sophisticated imaging systems for brain surgery and more accurate radiotherapy techniques are being developed, which would improve current SOC efficacy, reducing the morbidity and clinical deterioration associated to these therapies [280]. For example, there was found a correlation between hyperfractionated radiation and TMZ administration with CD4+ T-cell depletion in GBM patients, indicating immunosuppression [281]. This immunosuppressed state also correlated with worse 
prognosis [281]. Probably, the application of immune-stimulatory agents in an improved clinical setting might show an enhanced synergistic effect for the combinational approach with SOC.

Moreover, it is highly important to continue with the efforts to develop models that more faithfully recapitulate GBM features, in order to be able to predict more accurately the outcomes in the clinical setting. Finally, it would be necessary to find biomarkers that will help the neuro-oncologists and neurosurgeons to better select patients for clinical trials and to monitor the efficacy of the treatment or tumor progression.

\section{Funding}

This work was supported by NIH/NINDS Grants, R37-NS094804, R01-NS105556 and 1R21NS107894 to MG Castro.; NIH/NINDS Grants R01-NS076991, and R01-NS096756 to PR Lowenstein; NIH/NIBIB: R01-EB022563 grant to MG Castro., PR Lowenstein. and JJ Moon.; the Department of Neurosurgery, the Rogel Cancer Center, Program in Cancer Hematopoiesis and Immunology (CHI), the ChadTough Foundation, Pediatric Brain Tumor Foundation, and Leah's Happy Hearts to MG Castro. and PR Lowenstein.; RNA Biomedicine Grant F046166, Forbes Foundation Grant, University of Michigan Medical School, Rogel Cancer Center Scholar, University of Michigan Medical School to MG Castro.; T32 CA009676-26 Cancer Biology Training Grant to M Alghamri; UL1 TR002240 for the Michigan Institute for Clinical and Health Research (MICHR), Postdoctoral Translational Scholars Program (PTSP), Project F049768 to A Comba and American

Brain Tumor Association Basic Research Fellowship "in Memory of Bruce and Brian Jackson” to MBG Garcia-Fabiani

\section{$\underline{\text { Declaration of interest }}$}

The authors have no relevant affiliations or financial involvement with any organization or entity with a financial interest in or financial conflict with the subject matter or materials discussed in the 
manuscript. This includes employment, consultancies, honoraria, stock ownership or options, expert testimony, grants or patents received or pending, or royalties.

\section{$\underline{\text { Reviewer disclosures }}$}

Peer reviewers on this manuscript have no relevant financial or other relationships to disclose

\section{References}

Papers of special note have been highlighted as either of interest $(\bullet)$ or of considerable interest $(\bullet)$ to readers

[1] Ostrom QT, Gittleman H, Truitt G et al. CBTRUS statistical report: primary brain and other central nervous system tumors diagnosed in the United States in 2011-2015. Neuro-oncology 2018; 20:iv1-iv86.

[2] Waker CA, Lober RM. Brain Tumors of Glial Origin. In: Myelin. Springer; 2019. pp. 281-297.

[3] Louis DN, Perry A, Reifenberger G et al. The 2016 World Health Organization Classification of Tumors of the Central Nervous System: a summary. Acta Neuropathologica 2016;131:803-820.

[4] Verhaak RG. Moving the needle: Optimizing classification for glioma. Science translational medicine 2016; 8:350fs314.

[5] Yuan J, Levitin HM, Frattini V et al. Single-cell transcriptome analysis of lineage diversity in high-grade glioma. Genome medicine 2018; 10:57.

[6] Brennan CW, Verhaak RG, McKenna A et al. The somatic genomic landscape of glioblastoma. Cell 2013; 155:462-477.

[7] Teng J, da Hora CC, Kantar RS et al. Dissecting inherent intratumor heterogeneity in patient-derived glioblastoma culture models. Neuro Oncol 2017; 19:820-832.

[8] Mackay A, Burford A, Carvalho D et al. Integrated molecular meta-analysis of 1,000 pediatric high-grade and diffuse intrinsic pontine glioma. Cancer cell 2017; 32:520-537. e525.

[9] Bailey CP, Figueroa M, Mohiuddin S et al. Cutting Edge Therapeutic Insights Derived from Molecular Biology of Pediatric High-Grade Glioma and Diffuse Intrinsic Pontine Glioma (DIPG). Bioengineering (Basel, Switzerland) 2018; 5.

[10] Braunstein S, Raleigh D, Bindra R et al. Pediatric high-grade glioma: current molecular landscape and therapeutic approaches. Journal of neuro-oncology 2017; 134:541-549.

[11] Jones DTW, Banito A, Grunewald TGP et al. Molecular characteristics and therapeutic vulnerabilities across paediatric solid tumours. Nature reviews. Cancer 2019; 19:420-438.

[12] Fernandes C, Costa A, Osório L et al. Current standards of care in glioblastoma therapy. In: Glioblastoma [Internet]. Codon Publications; 2017.

[13] Kim BS, Seol HJ, Nam D-H et al. Concurrent chemoradiotherapy with temozolomide followed by adjuvant temozolomide for newly diagnosed glioblastoma patients: a retrospective multicenter observation study in Korea. Cancer research and treatment: official journal of Korean Cancer Association 2017; 49:193.

[14] Minniti G, Lanzetta G, Scaringi C et al. Phase II study of short-course radiotherapy plus concomitant and adjuvant temozolomide in elderly patients with glioblastoma. International Journal of Radiation Oncology* Biology* Physics 2012; 83:93-99. 
[15] Urgoiti GBR, Singh AD, Easaw JC. Extended adjuvant temozolomide for treatment of newly diagnosed glioblastoma multiforme. Journal of neuro-oncology 2012; 108:173-177.

[16] Bhandari M, Gandhi AK, Devnani B et al. Comparative study of adjuvant temozolomide six cycles versus extended 12 cycles in newly diagnosed glioblastoma multiforme. Journal of clinical and diagnostic research: JCDR 2017; 11:XC04.

[17] Barnett A, Knusel K, Ali A et al. Efficacy of Extended Adjuvant Temozolomide Cycle Duration in Newly Diagnosed Glioblastoma: Four-year experience of a single major tertiary care institution (P2. 6-035). In: AAN Enterprises; 2019.

[18] Bush NA, Chang SM, Berger MS. Current and future strategies for treatment of glioma. Neurosurgical review 2017; 40:1-14.

[19] Mallick S, Benson R, Hakim A, Rath GK. Management of glioblastoma after recurrence: A changing paradigm. Journal of the Egyptian National Cancer Institute 2016; 28:199-210.

[20] Chaichana KL, McGirt MJ, Laterra J et al. Recurrence and malignant degeneration after resection of adult hemispheric low-grade gliomas. Journal of neurosurgery 2010; 112:10-17.

[21] Keles GE, Lamborn KR, Berger MS. Low-grade hemispheric gliomas in adults: a critical review of extent of resection as a factor influencing outcome. Journal of neurosurgery 2001; 95:735-745.

[22] Fukuya $Y$, Ikuta S, Maruyama T et al. Tumor recurrence patterns after surgical resection of intracranial lowgrade gliomas. Journal of neuro-oncology 2019; 144:519-528.

[23] Xiong L, Wang F, Qi Xie X. Advanced treatment in high-grade gliomas. Journal of B.U.ON. : official journal of the Balkan Union of Oncology 2019; 24:424-430.

[24] Mrugala MM. Advances and challenges in the treatment of glioblastoma: a clinician's perspective. Discovery medicine 2013; 15:221-230.

[25] Nduom EK, Weller M, Heimberger AB. Immunosuppressive mechanisms in glioblastoma. Neuro-oncology 2015; 17 Suppl 7:vii9-vii14.

[26] Kamran N, Kadiyala P, Saxena M et al. Immunosuppressive myeloid cells' blockade in the glioma microenvironment enhances the efficacy of immune-stimulatory gene therapy. Molecular Therapy 2017;

25:232-248.

[27] Calinescu AA, Kamran N, Baker G et al. Overview of current immunotherapeutic strategies for glioma. Immunotherapy 2015; 7:1073-1104.

[28] Kamran N, Kadiyala P, Saxena M et al. Immunosuppressive Myeloid Cells' Blockade in the Glioma Microenvironment Enhances the Efficacy of Immune-Stimulatory Gene Therapy. Molecular therapy : the journal of the American Society of Gene Therapy 2017; 25:232-248.

[29] Lim M, Xia Y, Bettegowda C, Weller M. Current state of immunotherapy for glioblastoma. Nature reviews. Clinical oncology 2018; 15:422-442.

[30] Medawar PB. Immunity to homologous grafted skin. III. The fate of skin homographs transplanted to the brain, to subcutaneous tissue, and to the anterior chamber of the eye. British journal of experimental pathology 1948; 29:58.

[31] Shirai Y. On the transplantation of the rat sarcoma in adult heterogenous animals. Jap Med World 1921; 1:14-15.

[32] Murphy JB, Sturm E. Conditions determining the transplantability of tissues in the brain. The Journal of experimental medicine 1923; 38:183-197.

[33] Engelhardt B, Vajkoczy P, Weller RO. The movers and shapers in immune privilege of the CNS. Nat Immunol 2017; 18:123-131.

[34] Louveau A, Smirnov I, Keyes TJ et al. Structural and functional features of central nervous system lymphatic vessels. Nature 2015; 523:337-341.

[35] Kida S, Pantazis A, Weller RO. CSF drains directly from the subarachnoid space into nasal lymphatics in the rat. Anatomy, histology and immunological significance. Neuropathology and applied neurobiology 1993;

19:480-488. 
[36] Hu X, Deng Q, Ma L et al. Meningeal lymphatic vessels regulate brain tumor drainage and immunity. Cell Research 2020:1-15.

[37] Galea I, Bechmann I, Perry VH. What is immune privilege (not)? Trends in immunology 2007; 28:12-18.

[38] Negi N, Das BK. CNS: Not an immunoprivilaged site anymore but a virtual secondary lymphoid organ. International reviews of immunology 2018; 37:57-68.

[39] Saetta AA, Levidou G, El-Habr EA et al. Expression of pERK and PAKT in human astrocytomas: correlation with IDH1-R132H presence, vascular endothelial growth factor, microvascular characteristics and clinical outcome. Virchows Archiv 2011; 458:749-759.

[40] Yalaza C, Ak H, Cagli MS et al. R132H Mutation in IDH1 Gene is Associated with Increased Tumor HIF1-Alpha and Serum VEGF Levels in Primary Glioblastoma Multiforme. Ann Clin Lab Sci 2017; 47:362-364.

[41] Razavi SM, Lee KE, Jin BE et al. Immune Evasion Strategies of Glioblastoma. Front Surg 2016; 3:11.

[42] Van Meir EG. Cytokines and tumors of the central nervous system. Glia 1995; 15:264-288.

[43] Huettner C, Czub S, Kerkau S et al. Interleukin 10 is expressed in human gliomas in vivo and increases glioma cell proliferation and motility in vitro. Anticancer Res 1997; 17:3217-3224.

[44] Crane CA, Ahn BJ, Han SJ, Parsa AT. Soluble factors secreted by glioblastoma cell lines facilitate recruitment, survival, and expansion of regulatory T cells: implications for immunotherapy. Neuro-Oncology 2012; 14:584595.

[45] Akasaki Y, Liu G, Chung NHC et al. Induction of a CD4\&lt;sup\&gt;+\&lt;/sup\&gt; T Regulatory Type 1 Response by Cyclooxygenase-2-Overexpressing Glioma. The Journal of Immunology 2004; 173:4352.

[46] Jackson C, Ruzevick J, Phallen J et al. Challenges in immunotherapy presented by the glioblastoma multiforme microenvironment. Clin Dev Immunol 2011; 2011:732413.

[47] Rodrigues JC, Gonzalez GC, Zhang L et al. Normal human monocytes exposed to glioma cells acquire myeloid-derived suppressor cell-like properties. Neuro-oncology 2010; 12:351-365.

[48] Hao C, Parney IF, Roa WH et al. Cytokine and cytokine receptor mRNA expression in human glioblastomas: evidence of Th1, Th2 and Th3 cytokine dysregulation. Acta neuropathologica 2002; 103:171-178.

[49] Kamran N, Chandran M, Lowenstein PR, Castro MG, Immature myeloid cells in the tumor microenvironment: Implications for immunotherapy. Clinical Immunology 2018; 189:34-42.

[50] Kamran N, Alghamri MS, Nunez FJ et al. Current state and future prospects of immunotherapy for glioma. Immunotherapy 2018; 10:317-339.

[51] Rahbar A, Cederarv M, Wolmer-Solberg N et al. Enhanced neutrophil activity is associated with shorter time to tumor progression in glioblastoma patients. Oncoimmunology 2016; 5:e1075693.

[52] Brown NF, Carter TJ, Ottaviani D, Mulholland P. Harnessing the immune system in glioblastoma. British Journal of Cancer 2018; 119:1171-1181.

[53] Chen Z, Hambardzumyan D. Immune Microenvironment in Glioblastoma Subtypes. Frontiers in Immunology 2018; 9.

[54] Quail DF, Joyce JA. The Microenvironmental Landscape of Brain Tumors. Cancer Cell 2017; 31:326-341.

[55] Held-Feindt J, Hattermann K, Müerköster SS et al. CX3CR1 promotes recruitment of human glioma-

infiltrating microglia/macrophages (GIMs). Experimental Cell Research 2010; 316:1553-1566.

[56] Okada M, Saio M, Kito $\mathrm{Y}$ et al. Tumor-associated macrophage/microglia infiltration in human gliomas is correlated with MCP-3, but not MCP-1. Int J Oncol 2009; 34:1621-1627.

[57] da Fonseca AC, Badie B. Microglia and macrophages in malignant gliomas: recent discoveries and implications for promising therapies. Clin Dev Immunol 2013; 2013:264124.

[58] Kmiecik J, Zimmer J, Chekenya M. Natural killer cells in intracranial neoplasms: presence and therapeutic efficacy against brain tumours. Journal of neuro-oncology 2014; 116:1-9.

[59] Baker GJ, Chockley P, Yadav VN et al. Natural Killer Cells Eradicate Galectin-1-Deficient Glioma in the Absence of Adaptive Immunity. Cancer Research 2014; 74:5079.

[60] Chang AL, Miska J, Wainwright DA et al. CCL2 Produced by the Glioma Microenvironment Is Essential for the Recruitment of Regulatory T Cells and Myeloid-Derived Suppressor Cells. Cancer research 2016; 76:5671-5682. 
[61] Wainwright DA, Balyasnikova IV, Chang AL et al. IDO Expression in Brain Tumors Increases the Recruitment of Regulatory T Cells and Negatively Impacts Survival. Clinical Cancer Research 2012; 18:6110.

[62] Han S, Ma E, Wang X et al. Rescuing defective tumor-infiltrating T-cell proliferation in glioblastoma patients. Oncology letters 2016; 12:2924-2929.

[63] Woroniecka K, Chongsathidkiet P, Rhodin K et al. T-Cell Exhaustion Signatures Vary with Tumor Type and Are Severe in Glioblastoma. Clinical Cancer Research 2018; 24:4175.

[64] Haanen JB, Robert C. Immune checkpoint inhibitors. In: Immuno-Oncology. Karger Publishers; 2015. pp. 5566.

[65] Abril-Rodriguez G, Ribas A. SnapShot: immune checkpoint inhibitors. Cancer Cell 2017; 31:848-848. e841.

[66] Wherry EJ. T cell exhaustion. Nature immunology 2011; 12:492.

[67] Lamberti G, Franceschi E, Brandes AA. The burden of oncology promises not kept in glioblastoma. In: Future Medicine; 2018.

[68] Maxwell R, Jackson CM, Lim M. Clinical trials investigating immune checkpoint blockade in glioblastoma. Current treatment options in oncology 2017; 18:51.

[69] Simon S, Labarriere N. PD-1 expression on tumor-specific T cells: Friend or foe for immunotherapy? Oncoimmunology 2018; 7:e1364828.

[70] Chen DS, Mellman I. Oncology meets immunology: the cancer-immunity cycle. Immunity 2013; 39:1-10.

[71] Young JS, Dayani F, Morshed RA et al. Immunotherapy for high grade gliomas: a clinical update and practical considerations for neurosurgeons. World neurosurgery 2019.

[72] Nduom EK, Wei J, Yaghi NK et al. PD-L1 expression and prognostic impact in glioblastoma. Neuro-oncology 2015; 18:195-205.

[73] McGranahan T, Therkelsen KE, Ahmad S, Nagpal S. Current State of Immunotherapy for Treatment of Glioblastoma. Current treatment options in oncology 2019; 20:24.

[74] Li Y, Ali S, Clarke J, Cha S. Bevacizumab in recurrent glioma: patterns of treatment failure and implications. Brain tumor research and treatment 2017; 5:1-9.

[75] Zeng J, See AP, Phallen J et al. Anti-PD-1 blockade and stereotactic radiation produce long-term survival in mice with intracranial gliomas. International journal of radiation oncology, biology, physics 2013; 86:343-349.

[76] Wainwright DA, Chang AL, Dey M et al. Durable therapeutic efficacy utilizing combinatorial blockade against IDO, CTLA-4, and PD-L1 in mice with brain tumors. Clinical cancer research 2014; 20:5290-5301.

[77] Harris-Bookman S, Mathios D, Martin AM et al. Expression of LAG-3 and efficacy of combination treatment with anti-LAG-3 and anti-PD-1 monoclonal antibodies in glioblastoma. International journal of cancer 2018; 143:3201-3208.

[78] Vom Berg J, Vrohlings M, Haller S et al. Intratumoral IL-12 combined with CTLA-4 blockade elicits T cellmediated glioma rejection. Journal of Experimental Medicine 2013; 210:2803-2811.

[79] Fecci PE, Ochiai H, Mitchell DA et al. Systemic CTLA-4 Blockade Ameliorates Glioma-Induced Changes to the CD4+ T Cell Compartment without Affecting Regulatory T-Cell Function. Clinical Cancer Research 2007; 13:21582167.

[80] Omuro A, Vlahovic G, Lim M et al. Nivolumab with or without ipilimumab in patients with recurrent glioblastoma: results from exploratory phase I cohorts of CheckMate 143. Neuro-Oncology 2018; 20:674-686. [81] Reardon D, Omuro A, Brandes A et al. OS10. 3 randomized phase 3 study evaluating the efficacy and safety of nivolumab vs bevacizumab in patients with recurrent glioblastoma: CheckMate 143. Neuro-oncology 2017; 19:iii21-iii21.

[82] Cloughesy TF, Mochizuki AY, Orpilla JR et al. Neoadjuvant anti-PD-1 immunotherapy promotes a survival benefit with intratumoral and systemic immune responses in recurrent glioblastoma. Nature medicine 2019; 25:477.

[83] Hung AL, Maxwell R, Theodros D et al. TIGIT and PD-1 dual checkpoint blockade enhances antitumor immunity and survival in GBM. Oncoimmunology 2018; 7:e1466769. 
[84] Jahan $\mathrm{N}$, Talat $\mathrm{H}$, Alonso A et al. Triple combination immunotherapy with GVAX, anti-PD-1 monoclonal antibody, and agonist anti-OX40 monoclonal antibody is highly effective against murine intracranial glioma. Oncoimmunology 2019; 8:e1577108.

[85] Srinivasan VM, Ferguson SD, Lee S et al. Tumor Vaccines for Malignant Gliomas. Neurotherapeutics 2017; 14:345-357.

[86] Larry AH, Kirsten MH, Edward GA et al. Glioblastoma exosomes and IGF-1R/AS-ODN are immunogenic stimuli in a translational research immunotherapy paradigm. Cancer Immunol Immunother 2015; 64:299-309.

[87] Del Vecchio CA, Giacomini CP, Vogel H et al. EGFRvIll gene rearrangement is an early event in glioblastoma tumorigenesis and expression defines a hierarchy modulated by epigenetic mechanisms. Oncogene 2013;

32:2670-2681.

[88] Michael P. EGFRvIII vaccine in glioblastoma-InACT-IVe or not ReACTive enough? Neuro-oncology 2017; 19:1425-1426.

[89] Day BW, Stringer BW, Boyd AW. Eph receptors as therapeutic targets in glioblastoma. Brit J Cancer 2014; 111:1255-1261.

[90] Bart T, Christine EB, Emanuela B et al. Significance of interleukin-13 receptor alpha 2-targeted glioblastoma therapy. Neuro-oncology 2014; 16:1304-1312.

[91] Tran T, Diniz MO, Dransart E et al. A Therapeutic Her2/neu Vaccine Targeting Dendritic Cells Preferentially Inhibits the Growth of Low Her2/neu-Expressing Tumor in HLA-A2 Transgenic Mice. Clinical Cancer Research 2016; 22:4133.

[92] Fabio MI, Adília H. Unveiling YKL-40, from Serum Marker to Target Therapy in Glioblastoma. Frontiers Oncol 2014; 4:90.

[93] Shraibman B, Barnea E, Kadosh DM et al. Identification of Tumor Antigens Among the HLA Peptidomes of Glioblastoma Tumors and Plasma. Mol Cell Proteomics 2018; 17:2132-2145.

[94] Jiang T, Shi T, Zhang H et al. Tumor neoantigens: from basic research to clinical applications. J Hematol Oncol 2019; 12:93.

[95] Johanns TM, Bowman-Kirigin JA, Liu C, Dunn GP. Targeting Neoantigens in Glioblastoma: An Overview of Cancer Immunogenomics and Translational Implications. Neurosurgery 2017; 64:165-176.

[96] Theresa S, Lukas B, Wolfgang W, Michael P. Mutant IDH1: An immunotherapeutic target in tumors. Oncoimmunology 2014; 3:e974392.

[97] Chheda ZS, Kohanbash G, Okada K et al. Novel and shared neoantigen derived from histone 3 variant H3.3K27M mutation for glioma T cell therapy. The Journal of experimental medicine 2018; 215:141-157.

[98] Keskin DB, Anandappa AJ, Sun J et al. Neoantigen vaccine generates intratumoral T cell responses in phase Ib glioblastoma trial. Nature 2019; 565:234.

[99] Timothy FC, Aaron YM, Joey RO et al. Neoadjuvant anti-PD-1 immunotherapy promotes a survival benefit with intratumoral and systemic immune responses in recurrent glioblastoma. Nat Med 2019; 25:477-486.

[100] Romani M, Pistillo MP, Carosio R et al. Immune checkpoints and innovative therapies in glioblastoma. Frontiers in oncology 2018; 8.

[101] Burris H, Infante J, Ansell S et al. Safety and Activity of Varlilumab, a Novel and First-in-Class Agonist AntiCD27 Antibody, in Patients With Advanced Solid Tumors. Journal of clinical oncology : official journal of the American Society of Clinical Oncology 2017; 35:JCO2016701508.

[102] Ascarateil S, Puget A, Koziol M-E. Safety data of Montanide ISA 51 VG and Montanide ISA 720 VG, two adjuvants dedicated to human therapeutic vaccines. J Immunother Cancer 2015; 3:P428-P428.

[103] Fenstermaker RA, Ciesielski MJ, Qiu J et al. Clinical study of a survivin long peptide vaccine (SurVaxM) in patients with recurrent malignant glioma. Cancer Immunol Immunother 2016; 65:1339-1352.

[104] Leary R, Gardner RB, Mockbee C, Roychowdhury DF. Boosting Abscopal Response to Radiotherapy with Sargramostim: A Review of Data and Ongoing Studies. Cureus 2019; 11:e4276.

[105] Benencia F, Sprague L, McGinty J et al. Dendritic cells the tumor microenvironment and the challenges for an effective antitumor vaccination. J Biomed Biotechnol 2012; 2012:425476. 
[106] Blanco P, Palucka AK, Pascual V, Banchereau J. Dendritic cells and cytokines in human inflammatory and autoimmune diseases. Cytokine Growth Factor Rev 2008; 19:41-52.

[107] Garg AD CP, Van den Eynde BJ, Agostinis P. Integrating Next Generation Dendritic Cell Vaccines into the Current Cancer Immunotherap Landscape. Epub 2017 Aug:577-593.

[108] Schaller TH, Sampson JH. Advances and challenges: dendritic cell vaccination strategies for glioblastoma. Expert Rev Vaccines 2017; 16:27-36.

[109] Srivastava S, Jackson C, Kim T et al. A Characterization of Dendritic Cells and Their Role in Immunotherapy in Glioblastoma: From Preclinical Studies to Clinical Trials. Cancers 2019; 11:537.

[110] Bregy A, Wong TM, Shah AH et al. Active immunotherapy using dendritic cells in the treatment of glioblastoma multiforme. Cancer Treatment Reviews 2013; 39:891-907.

[111] Belmans J, Van Woensel M, Creyns B et al. Immunotherapy with subcutaneous immunogenic autologous tumor lysate increases murine glioblastoma survival. Sci Rep 2017; 7:13902.

[112] Vichchatorn P, Wongkajornsilp A, Petvises S et al. Dendritic cells pulsed with total tumor RNA for activation NK-like T cells against glioblastoma multiforme. J Neurooncol 2005; 75:111-118.

[113] Lundstrom K. Latest development on RNA-based drugs and vaccines. Future Sci OA 2018; 4:FSO300. [114] Scheurer ME, Bondy ML, Aldape KD et al. Detection of human cytomegalovirus in different histological types of gliomas. Acta Neuropathol 2008; 116:79-86.

[115] Cobbs CS, Harkins L, Samanta M et al. Human cytomegalovirus infection and expression in human malignant glioma. Cancer research 2002; 62:3347-3350.

[116] Dziurzynski K, Chang SM, Heimberger AB et al. Consensus on the role of human cytomegalovirus in glioblastoma. Neuro Oncol 2012; 14:246-255.

[117] Batich KA, Reap EA, Archer GE et al. Long-term Survival in Glioblastoma with Cytomegalovirus pp65Targeted Vaccination. Clin Cancer Res 2017; 23:1898-1909.

[118] Zapatka M, Borozan I, Brewer DS et al. The landscape of viral associations in human cancers. Nature genetics 2020.

[119] Holdhoff M, Guner G, Rodriguez FJ et al. Absence of Cytomegalovirus in Glioblastoma and Other Highgrade Gliomas by Real-time PCR, Immunohistochemistry, and In Situ Hybridization. Clinical cancer research : an official journal of the American Association for Cancer Research 2017; 23:3150-3157.

[120] Garcia-Martinez A, Alenda C, Irles E et al. Lack of cytomegalovirus detection in human glioma. Virology journal 2017; 14:216.

[121] Benitez-Ribas D, Cabezon R, Florez-Grau G et al. Immune Response Generated With the Administration of Autologous Dendritic Cells Pulsed With an Allogenic Tumoral Cell-Lines Lysate in Patients With Newly Diagnosed Diffuse Intrinsic Pontine Glioma. Front Oncol 2018; 8:127.

[122] Prins RM, Craft N, Bruhn KW et al. The TLR-7 agonist, imiquimod, enhances dendritic cell survival and promotes tumor antigen-specific T cell priming: relation to central nervous system antitumor immunity. J Immunol 2006; 176:157-164.

[123] Michaelis KA, Norgard MA, Zhu X et al. The TLR7/8 agonist R848 remodels tumor and host responses to promote survival in pancreatic cancer. Nat Commun 2019; 10:4682-4682.

[124] Caisova V, Vieru A, Kumzakova Z et al. Innate immunity based cancer immunotherapy: B16-F10 murine melanoma model. BMC Cancer 2016; 16:940.

[125] Rodriguez-Ruiz ME, Perez-Gracia JL, Rodriguez I et al. Combined immunotherapy encompassing intratumoral poly-ICLC, dendritic-cell vaccination and radiotherapy in advanced cancer patients. Ann Oncol 2018; 29:1312-1319.

[126] Abarca-Merlin DM, Maldonado-Bernal C, Alvarez-Arellano L. Toll-Like Receptors as Therapeutic Targets in Central Nervous System Tumors. Biomed Res Int 2019; 2019:5286358-5286358.

[127] Mitchell DA, Batich KA, Gunn MD et al. Tetanus toxoid and CCL3 improve dendritic cell vaccines in mice and glioblastoma patients. Nature 2015; 519:366-369. 
[128] Eagles ME, Nassiri F, Badhiwala JH et al. Dendritic cell vaccines for high-grade gliomas. Therapeutics and Clinical Risk Management 2018; 14:1299.

[129] Van Gulijk M, Dammeijer F, Aerts JG, Vroman H. Combination strategies to optimize efficacy of dendritic cell-based immunotherapy. Frontiers in immunology 2018; 9.

[130] Karachi A, Dastmalchi F, Mitchell DA, Rahman M. Temozolomide for immunomodulation in the treatment of glioblastoma. Neuro-oncology 2018; 20:1566-1572.

[131] Iversen TZ, Brimnes MK, Nikolajsen K et al. Depletion of T lymphocytes is correlated with response to temozolomide in melanoma patients. Oncoimmunology 2013; 2:e23288.

[132] Sridharan Gururangan ES, Duane A. Mitchell. Total tumor RNA pulsed dendritic cells plus adoptive transfer of ex-vivo enriched autologous T-lymphocytes in the treatment of children with primary brain tumors.

Neuroimmunol Neuroinflammation 2018; 5.

[133] Kim MM, Umemura Y, Leung D. Bevacizumab and Glioblastoma: Past, Present, and Future Directions. Cancer J 2018; 24:180-186.

[134] Schalper KA, Rodriguez-Ruiz ME, Diez-Valle $R$ et al. Neoadjuvant nivolumab modifies the tumor immune microenvironment in resectable glioblastoma. Nat Med 2019; 25:470-476.

[135] Prestwich RJ, Harrington KJ, Pandha HS et al. Oncolytic viruses: a novel form of immunotherapy. Expert review of anticancer therapy 2008; 8:1581-1588.

[136] Chiocca EA, Rabkin SD. Oncolytic viruses and their application to cancer immunotherapy. Cancer immunology research 2014; 2:295-300.

[137] Aurelian L. Oncolytic viruses as immunotherapy: progress and remaining challenges. OncoTargets and therapy 2016; 9:2627.

[138] Hermiston TW, Kuhn I. Armed therapeutic viruses: strategies and challenges to arming oncolytic viruses with therapeutic genes. Cancer gene therapy 2002; 9:1022.

[139] Forsyth P, Roldan G, George D et al. A phase I trial of intratumoral (it) administration of reovirus in patients with histologically confirmed recurrent malignant gliomas (MGs). Journal of Clinical Oncology 2006; 24:15631563.

[140] Kicielinski KP, Chiocca EA, John SY et al. Phase 1 clinical trial of intratumoral reovirus infusion for the treatment of recurrent malignant gliomas in adults. Molecular Therapy 2014; 22:1056-1062.

[141] Samson A, Scott KJ, Taggart D et al. Intravenous delivery of oncolytic reovirus to brain tumor patients immunologically primes for subsequent checkpoint blockade. Science translational medicine 2018;

10:eaam7577.

[142] Martuza RL, Malick A, Markert JM et al. Experimental therapy of human glioma by means of a genetically engineered virus mutant. Science 1991; 252:854-856.

[143] Markert J, Medlock M, Rabkin S et al. Conditionally replicating herpes simplex virus mutant, G207 for the treatment of malignant glioma: results of a phase I trial. Gene therapy 2000; 7:867.

[144] Markert JM, Liechty PG, Wang W et al. Phase Ib trial of mutant herpes simplex virus G207 inoculated preand post-tumor resection for recurrent GBM. Molecular Therapy 2009; 17:199-207.

[145] Markert JM, Razdan SN, Kuo HC et al. A phase 1 trial of oncolytic HSV-1, G207, given in combination with radiation for recurrent GBM demonstrates safety and radiographic responses. Molecular therapy : the journal of the American Society of Gene Therapy 2014; 22:1048-1055.

[146] Kambara H, Okano H, Chiocca EA, Saeki Y. An oncolytic HSV-1 mutant expressing ICP34. 5 under control of a nestin promoter increases survival of animals even when symptomatic from a brain tumor. Cancer research 2005; 65:2832-2839.

[147] Cassady KA, Bauer DF, Roth J et al. Pre-clinical assessment of C134, a chimeric oncolytic herpes simplex virus, in mice and non-human primates. Molecular Therapy-Oncolytics 2017; 5:1-10.

[148] Fueyo J, Gomez-Manzano C, Alemany R et al. A mutant oncolytic adenovirus targeting the Rb pathway produces anti-glioma effect in vivo. Oncogene 2000; 19:2. 
[149] Fueyo J, Alemany R, Gomez-Manzano C et al. Preclinical characterization of the antiglioma activity of a tropism-enhanced adenovirus targeted to the retinoblastoma pathway. Journal of the National Cancer Institute 2003; 95:652-660.

[150] Lang FF, Conrad C, Gomez-Manzano C et al. Phase I study of DNX-2401 (Delta-24-RGD) oncolytic adenovirus: replication and immunotherapeutic effects in recurrent malignant glioma. Journal of Clinical Oncology 2018; 36:1419.

[151] Dobrikova EY, Goetz C, Walters RW et al. Attenuation of neurovirulence, biodistribution, and shedding of a poliovirus: rhinovirus chimera after intrathalamic inoculation in Macaca fascicularis. Journal of virology 2012;

86:2750-2759.

[152] Mendelsohn CL, Wimmer E, Racaniello VR. Cellular receptor for poliovirus: molecular cloning, nucleotide sequence, and expression of a new member of the immunoglobulin superfamily. Cell 1989; 56:855-865.

[153] Chandramohan V, Bryant JD, Piao H et al. Validation of an Immunohistochemistry Assay for Detection of CD155, the Poliovirus Receptor, in Malignant Gliomas. Arch Pathol Lab Med 2017; 141:1697-1704.

[154] Brown MC, Holl EK, Boczkowski D et al. Cancer immunotherapy with recombinant poliovirus induces IFNdominant activation of dendritic cells and tumor antigen-specific CTLs. Science translational medicine 2017; 9:eaan4220.

[155] Heufler C, Koch F, Stanzl U et al. Interleukin-12 is produced by dendritic cells and mediates T helper 1 development as well as interferon- $\nu$ production by T helper 1 cells. European journal of immunology 1996; 26:659-668.

[156] Atkins MB, Robertson MJ, Gordon M et al. Phase I evaluation of intravenous recombinant human interleukin 12 in patients with advanced malignancies. Clinical Cancer Research 1997; 3:409-417.

[157] Leonard JP, Sherman ML, Fisher GL et al. Effects of single-dose interleukin-12 exposure on interleukin-12associated toxicity and interferon-gamma production. Blood 1997; 90:2541-2548.

[158] Barrett JA, Cai H, Miao J et al. Regulated intratumoral expression of IL-12 using a RheoSwitch Therapeutic System ${ }^{\circledast}\left(\right.$ RTS $\left.^{\circledast}\right)$ gene switch as gene therapy for the treatment of glioma. Cancer gene therapy 2018; 25:106. [159] Chiocca EA, John SY, Lukas RV et al. Regulatable interleukin-12 gene therapy in patients with recurrent high-grade glioma: Results of a phase 1 trial. Science translational medicine 2019; 11:eaaw5680.

[160] Curtin JF, King GD, Barcia C et al. Fms-like tyrosine kinase 3 ligand recruits plasmacytoid dendritic cells to the brain. The Journal of Immunology 2006; 176:3566-3577.

[161] Candolfi M, King GD, Yagiz K et al. Plasmacytoid dendritic cells in the tumor microenvironment: immune targets for glioma therapeutics. Neoplasia (New York, NY) 2012; 14:757.

[162] Larocque D, Sanderson NS, Bergeron J et al. Exogenous fms-like tyrosine kinase 3 ligand overrides brain immune privilege and facilitates recognition of a neo-antigen without causing autoimmune neuropathology. Proceedings of the National Academy of Sciences of the United States of America 2010; 107:14443-14448. [163] Muhammad AG, Candolfi M, King GD et al. Antiglioma immunological memory in response to conditional cytotoxic/immune-stimulatory gene therapy: humoral and cellular immunity lead to tumor regression. Clinical Cancer Research 2009; 15:6113-6127.

[164] Ali S, King GD, Curtin JF et al. Combined immunostimulation and conditional cytotoxic gene therapy provide long-term survival in a large glioma model. Cancer research 2005; 65:7194-7204.

[165] Candolfi M, Yagiz K, Foulad D et al. Release of HMGB1 in response to proapoptotic glioma killing strategies: efficacy and neurotoxicity. Clinical Cancer Research 2009; 15:4401-4414.

[166] Abarca-Merlin DM, Maldonado-Bernal C, Alvarez-Arellano L. Toll-Like Receptors as Therapeutic Targets in Central Nervous System Tumors. BioMed research international 2019; 2019:5286358.

[167] Curtin JF, Edwards MR, Michelsen KS et al. HMGB1 Mediates Endogenous TLR2 Activation And Brain Tumor Regression. In: Federation of American Societies for Experimental Biology; 2008.

[168] Puntel M, Muhammad AK, Candolfi M et al. A novel bicistronic high-capacity gutless adenovirus vector that drives constitutive expression of herpes simplex virus type 1 thymidine kinase and tet-inducible expression of Flt3L for glioma therapeutics. J Virol 2010; 84:6007-6017. 
[169] Mineharu Y, Muhammad AK, Yagiz K et al. Gene therapy-mediated reprogramming tumor infiltrating T cells using IL-2 and inhibiting NF-kappaB signaling improves the efficacy of immunotherapy in a brain cancer model. Neurotherapeutics : the journal of the American Society for Experimental NeuroTherapeutics 2012; 9:827-843.

[170] Assi H, Candolfi M, Baker G et al. Gene therapy for brain tumors: basic developments and clinical implementation. Neuroscience letters 2012; 527:71-77.

[171] Muhammad AK, Puntel M, Candolfi M et al. Study of the efficacy, biodistribution, and safety profile of therapeutic gutless adenovirus vectors as a prelude to a phase I clinical trial for glioblastoma. Clinical pharmacology and therapeutics 2010; 88:204-213.

[172] Muhammad AK, Xiong W, Puntel M et al. Safety profile of gutless adenovirus vectors delivered into the normal brain parenchyma: implications for a glioma phase 1 clinical trial. Human gene therapy methods 2012; 23:271-284.

[173] Chiocca EA, Aguilar LK, Bell SD et al. Phase IB study of gene-mediated cytotoxic immunotherapy adjuvant to up-front surgery and intensive timing radiation for malignant glioma. Journal of clinical oncology 2011; 29:3611.

[174] Westphal M, Ylä-Herttuala S, Martin J et al. Adenovirus-mediated gene therapy with sitimagene ceradenovec followed by intravenous ganciclovir for patients with operable high-grade glioma (ASPECT): a randomised, open-label, phase 3 trial. The Lancet Oncology 2013; 14:823-833.

[175] Maus MV, June CH. Making better chimeric antigen receptors for adoptive T-cell therapy. In: AACR; 2016. [176] Benmebarek M-R, Karches CH, Cadilha BL et al. Killing mechanisms of chimeric antigen receptor (CAR) T cells. International journal of molecular sciences 2019; 20:1283.

[177] Sadelain M, Brentjens R, Rivière I. The basic principles of chimeric antigen receptor design. Cancer discovery 2013; 3:388-398.

[178] Fesnak AD, June CH, Levine BL. Engineered T cells: the promise and challenges of cancer immunotherapy. Nature Reviews Cancer 2016; 16:566.

[179] Porter DL, Hwang W-T, Frey NV et al. Chimeric antigen receptor T cells persist and induce sustained remissions in relapsed refractory chronic lymphocytic leukemia. Science translational medicine 2015; 7:303ra139-303ra139.

[180] Buechner J, Grupp SA, Maude SL et al. Global registration trial of efficacy and safety of CTL019 in pediatric and young adult patients with relapsed/refractory (R/R) acute lymphoblastic leukemia (ALL): update to the interim analysis. Clinical Lymphoma, Myeloma and Leukemia 2017; 17:S263-S264.

[181] Charles NA, Holland EC, Gilbertson R et al. The brain tumor microenvironment. Glia 2012; 60:502-514. [182] Akhavan D, Alizadeh D, Wang D et al. CAR T cells for brain tumors: Lessons learned and road ahead. Immunological reviews 2019; 290:60-84.

[183] Bagley SJ, Desai AS, Linette GP et al. CAR T-cell therapy for glioblastoma: recent clinical advances and future challenges. Neuro Oncol 2018; 20:1429-1438.

[184] Filley AC, Henriquez M, Dey M. CART Immunotherapy: Development, Success, and Translation to Malignant Gliomas and Other Solid Tumors. Front Oncol 2018; 8:453.

[185] Mount CW, Majzner RG, Sundaresh S et al. Potent antitumor efficacy of anti-GD2 CAR T cells in H3-K27M+ diffuse midline gliomas. Nature medicine 2018; 24:572.

[186] Nehama D, Di lanni N, Musio S et al. B7-H3-redirected chimeric antigen receptor T cells target glioblastoma and neurospheres. EBioMedicine 2019; 47:33-43.

[187] Tang X, Zhao S, Zhang Y et al. B7-H3 as a novel CAR-T therapeutic target for glioblastoma. Molecular Therapy-Oncolytics 2019; 14:279-287.

[188] Yi Z, Prinzing BL, Cao F et al. Optimizing EphA2-CAR T cells for the adoptive immunotherapy of glioma. Molecular Therapy-Methods \& Clinical Development 2018; 9:70-80.

[189] Chow KK, Naik S, Kakarla S et al. T cells redirected to EphA2 for the immunotherapy of glioblastoma. Molecular Therapy 2013; 21:629-637. 
[190] Miao H, Choi BD, Suryadevara CM et al. EGFRvIll-specific chimeric antigen receptor T cells migrate to and kill tumor deposits infiltrating the brain parenchyma in an invasive xenograft model of glioblastoma. PloS one 2014; 9:e94281.

[191] Sampson JH, Choi BD, Sanchez-Perez L et al. EGFRvIII mCAR-modified T-cell therapy cures mice with established intracerebral glioma and generates host immunity against tumor-antigen loss. Clinical cancer research : an official journal of the American Association for Cancer Research 2014; 20:972-984.

[192] Krenciute G, Krebs S, Torres D et al. Characterization and Functional Analysis of scFv-based Chimeric Antigen Receptors to Redirect T Cells to IL13Ra2-positive Glioma. Molecular Therapy: The Journal of the American Society of Gene Therapy 2016; 24:354-363.

[193] Kahlon KS, Brown C, Cooper $\amalg$ et al. Specific recognition and killing of glioblastoma multiforme by interleukin 13-zetakine redirected cytolytic T cells. Cancer research 2004; 64:9160-9166.

[194] Zhang C, Burger MC, Jennewein L et al. ErbB2/HER2-Specific NK Cells for Targeted Therapy of Glioblastoma. Journal of the National Cancer Institute 2016; 108.

[195] Ahmed N, Salsman VS, Kew Y et al. HER2-specific T cells target primary glioblastoma stem cells and induce regression of autologous experimental tumors. Clinical cancer research : an official journal of the American Association for Cancer Research 2010; 16:474-485.

[196] Brown CE, Badie B, Barish ME et al. Bioactivity and Safety of IL13R 2-Redirected Chimeric Antigen Receptor CD8+ T Cells in Patients with Recurrent Glioblastoma. Clinical Cancer Research 2015; 21:4062-4072.

[197] O'Rourke DM, Nasrallah MP, Desai A et al. A single dose of peripherally infused EGFRvIll-directed CAR T cells mediates antigen loss and induces adaptive resistance in patients with recurrent glioblastoma. Science translational medicine 2017; 9.

[198] Ahmed N, Brawley V, Hegde M et al. HER2-Specific Chimeric Antigen Receptor-Modified Virus-Specific T Cells for Progressive Glioblastoma: A Phase 1 Dose-Escalation Trial. JAMA Oncol 2017; 3:1094-1101.

[199] Bagley SJ, Desai AS, Linette GP et al. CAR T-cell therapy for glioblastoma: recent clinical advances and future challenges. Neuro-Oncology 2018; 20:1429-1438.

[200] Chuntova P, Downey KM, Hegde B et al. Genetically Engineered T-Cells for Malignant Glioma: Overcoming the Barriers to Effective Immunotherapy. Front Immunol 2018; 9:3062.

[201] Brown CE, Alizadeh D, Starr R et al. Regression of glioblastoma after chimeric antigen receptor T-cell therapy. New England Journal of Medicine 2016; 375:2561-2569.

[202] Choi BD, Suryadevara CM, Gedeon PC et al. Intracerebral delivery of a third generation EGFRvIII-specific chimeric antigen receptor is efficacious against human glioma. Journal of clinical neuroscience : official journal of the Neurosurgical Society of Australasia 2014; 21:189-190.

[203] Cornelissen MJ, de Goederen R, Doerga P et al. Pilot study of intracranial venous physiology in craniosynostosis. Journal of Neurosurgery. Pediatrics 2018; 21:626-631.

[204] Choi BD, Yu X, Castano AP et al. CAR-T cells secreting BiTEs circumvent antigen escape without detectable toxicity. Nature biotechnology 2019; 37:1049-1058.

[205] Choi BD, Yu X, Castano AP et al. CRISPR-Cas9 disruption of PD-1 enhances activity of universal EGFRvIII CAR T cells in a preclinical model of human glioblastoma. Journal for ImmunoTherapy of Cancer 2019; 7:1-8.

[206] Krenciute G, Prinzing BL, Yi Z et al. Transgenic Expression of IL15 Improves Antiglioma Activity of IL13R $\alpha 2-$ CAR T Cells but Results in Antigen Loss Variants. Cancer Immunology Research 2017; 5:571-581.

[207] Hegde M, Corder A, Chow KK et al. Combinational targeting offsets antigen escape and enhances effector functions of adoptively transferred T cells in glioblastoma. Molecular Therapy 2013; 21:2087-2101.

[208] Hegde M, Mukherjee M, Grada Z et al. Tandem CAR T cells targeting HER2 and IL13Ralpha2 mitigate tumor antigen escape. The Journal of clinical investigation 2016; 126:3036-3052.

[209] Bielamowicz K, Fousek K, Byrd TT et al. Trivalent CAR T cells overcome interpatient antigenic variability in glioblastoma. Neuro Oncol 2018; 20:506-518.

[210] Jiang $\mathrm{H}$, Gao H, Kong J et al. Selective targeting of glioblastoma with EGFRvIII/EGFR Bi-targeted chimeric antigen receptor T cell. Cancer immunology research 2018:canimm. 0044.2018. 
[211] Mitra S, Li G, Harsh GR. Passive antibody-mediated immunotherapy for the treatment of malignant gliomas. Neurosurgery Clinics 2010; 21:67-76.

[212] Nagasawa DT, Fong C, Yew A et al. Passive immunotherapeutic strategies for the treatment of malignant gliomas. Neurosurgery Clinics 2012; 23:481-495.

[213] Sharma A, Low J, Mrugala MM. Neuro-oncologists have spoken-the role of bevacizumab in the inpatient setting. A clinical and economic conundrum. Neuro-Oncology Practice 2018; 6:30-36.

[214] Seystahl K, Hentschel B, Loew S et al. Bevacizumab versus alkylating chemotherapy in recurrent glioblastoma. Journal of cancer research and clinical oncology 2019.

[215] Diaz RJ, Ali S, Qadir MG et al. The role of bevacizumab in the treatment of glioblastoma. Journal of neurooncology 2017; 133:455-467.

[216] Gilbert MR, Dignam JJ, Armstrong TS et al. A randomized trial of bevacizumab for newly diagnosed glioblastoma. The New England journal of medicine 2014; 370:699-708.

[217] Chinot OL, Wick W, Mason W et al. Bevacizumab plus radiotherapy-temozolomide for newly diagnosed glioblastoma. The New England journal of medicine 2014; 370:709-722.

[218] Everson RG, Graner MW, Gromeier M et al. Immunotherapy against angiogenesis-associated targets: evidence and implications for the treatment of malignant glioma. Expert review of anticancer therapy 2008; 8:717-732.

[219] Chen W, He D, Li Z et al. Overexpression of vascular endothelial growth factor indicates poor outcomes of glioma: a systematic review and meta-analysis. International journal of clinical and experimental medicine 2015; 8:8709.

[220] Grill J, Massimino M, Bouffet E et al. Phase II, Open-Label, Randomized, Multicenter Trial (HERBY) of Bevacizumab in Pediatric Patients With Newly Diagnosed High-Grade Glioma. Journal of clinical oncology : official journal of the American Society of Clinical Oncology 2018; 36:951-958.

[221] Keller S, Schmidt MHH. EGFR and EGFRvIII Promote Angiogenesis and Cell Invasion in Glioblastoma: Combination Therapies for an Effective Treatment. Int J Mol Sci 2017; 18.

[222] Nitta Y, Shimizu S, Shishido-Hara Y et al. Nimotuzumab enhances temozolomide-induced growth suppression of glioma cells expressing mutant EGFR in vivo. Cancer medicine 2016; 5:486-499.

[223] Phillips AC, Boghaert ER, Vaidya KS et al. ABT-414, an Antibody-Drug Conjugate Targeting a TumorSelective EGFR Epitope. Molecular cancer therapeutics 2016; 15:661-669.

[224] Xu W, Bi Y, Kong J et al. Combination of an anti-EGFRvIII antibody $\mathrm{CH} 12$ with Rapamycin synergistically inhibits the growth of EGFRvIII+PTEN-glioblastoma in vivo. Oncotarget 2016; 7:24752-24765.

[225] Reardon DA, Lassman AB, van den Bent $M$ et al. Efficacy and safety results of ABT-414 in combination with radiation and temozolomide in newly diagnosed glioblastoma. Neuro Oncol 2017; 19:965-975.

[226] Eskilsson E, Rosland GV, Solecki G et al. EGFR heterogeneity and implications for therapeutic intervention in glioblastoma. Neuro Oncol 2018; 20:743-752.

[227] Razpotnik R, Novak N, Čurin Šerbec V, Rajcevic U. Targeting malignant brain tumors with antibodies. Frontiers in immunology 2017; 8:1181.

[228] Regina A, Demeule M, Tripathy $S$ et al. ANG4043, a novel brain-penetrant peptide-mAb conjugate, is efficacious against HER2-positive intracranial tumors in mice. Molecular cancer therapeutics 2015; 14:129-140. [229] Parker Kerrigan BC, Hossain A, Yamashita S, Lang FF. Stem Cell Therapy of Gliomas. Progress in neurological surgery 2018; 32:124-151.

[230] Kloepper J, Riedemann L, Amoozgar Z et al. Ang-2/VEGF bispecific antibody reprograms macrophages and resident microglia to anti-tumor phenotype and prolongs glioblastoma survival. Proceedings of the National Academy of Sciences 2016; 113:4476-4481.

[231] Li J, Zhang Z, Lv L et al. A bispecific antibody (ScBsAbAgn-2/TSPO) target for Ang-2 and TSPO resulted in therapeutic effects against glioblastomas. Biochemical and biophysical research communications 2016; 472:384391. 
[232] Choi BD, Gedeon PC, Sanchez-Perez L et al. Regulatory T cells are redirected to kill glioblastoma by an EGFRvIll-targeted bispecific antibody. Oncoimmunology 2013; 2:e26757.

[233] Choi BD, Kuan C-T, Cai M et al. Systemic administration of a bispecific antibody targeting EGFRvIII successfully treats intracerebral glioma. Proceedings of the National Academy of Sciences 2013; 110:270-275. [234] Platten M, Wick W, Van den Eynde BJ. Tryptophan catabolism in cancer: beyond IDO and tryptophan depletion. Cancer research 2012; 72:5435-5440.

[235] Mellor AL, Munn DH. IDO expression by dendritic cells: tolerance and tryptophan catabolism. Nature Reviews Immunology 2004; 4:762.

[236] O'Connor JC, Lawson MA, André C et al. Induction of IDO by bacille Calmette-Guerin is responsible for development of murine depressive-like behavior. The Journal of Immunology 2009; 182:3202-3212.

[237] Uyttenhove C, Pilotte L, Théate I et al. Evidence for a tumoral immune resistance mechanism based on tryptophan degradation by indoleamine 2, 3-dioxygenase. Nature medicine 2003; 9:1269.

[238] Mitsuka K, Kawataki T, Satoh E et al. Expression of indoleamine 2, 3-dioxygenase and correlation with pathological malignancy in gliomas. Neurosurgery 2013; 72:1031-1039.

[239] Lacy MQ, Hayman SR, Gertz MA et al. Pomalidomide (CC4047) plus low-dose dexamethasone as therapy for relapsed multiple myeloma. Journal of clinical oncology : official journal of the American Society of Clinical Oncology 2009; 27:5008-5014.

[240] Fujiwara Y, Sun Y, Torphy RJ et al. Pomalidomide Inhibits PD-L1 Induction to Promote Antitumor Immunity. Cancer research 2018; 78:6655-6665.

[241] Quach H, Ritchie D, Stewart AK et al. Mechanism of action of immunomodulatory drugs (IMiDS) in multiple myeloma. Leukemia 2010; 24:22.

[242] Parrish K, Sarkaria JN, Elmquist WF. Improving drug delivery to primary and metastatic brain tumors: strategies to overcome the blood-brain barrier. Clinical Pharmacology \& Therapeutics 2015; 97:336-346.

[243] Tseng W-L, Hsu H-H, Chen Y, Tseng S-H. Tumor recurrence in a glioblastoma patient after discontinuation of prolonged temozolomide treatment. Asian Journal of Neurosurgery 2017; 12:727.

[244] Van Tellingen O, Yetkin-Arik B, De Gooijer M et al. Overcoming the blood-brain tumor barrier for effective glioblastoma treatment. Drug Resistance Updates 2015; 19:1-12.

[245] Zhang F, Xu C-L, Liu C-M. Drug delivery strategies to enhance the permeability of the blood-brain barrier for treatment of glioma. Drug Design, Development and Therapy 2015; 9:2089-2100.

[246] Lomis N, Westfall S, Farahdel L et al. Human Serum Albumin Nanoparticles for Use in Cancer Drug Delivery: Process Optimization and In Vitro Characterization. Nanomaterials (Basel, Switzerland) 2016; 6.

[247] Kuai R, Li D, Chen YE et al. High-Density Lipoproteins: Nature's Multifunctional Nanoparticles. ACS nano 2016; 10:3015-3041.

[248] Kuai R, Ochyl L, Bahjat KS et al. Designer vaccine nanodiscs for personalized cancer immunotherapy. Nature Materials 2017; 16:489-496.

[249] Agrahari V, Burnouf P-A, Burnouf T, Agrahari V. Nanoformulation properties, characterization, and behavior in complex biological matrices: Challenges and opportunities for brain-targeted drug delivery applications and enhanced translational potential. Advanced Drug Delivery Reviews 2019.

[250] Anchordoquy TJ, Barenholz Y, Boraschi D et al. Mechanisms and barriers in cancer nanomedicine: addressing challenges, looking for solutions. In: ACS Publications; 2017.

[251] Masserini M. Nanoparticles for Brain Drug Delivery. ISRN Biochemistry 2013; 2013:1-18.

[252] He H, Liu L, Morin EE et al. Survey of Clinical Translation of Cancer Nanomedicines-Lessons Learned from Successes and Failures. Accounts of chemical research 2019; 52:2445-2461.

[253] Kadiyala P, Li D, Nuñez FM et al. High-Density Lipoprotein-Mimicking Nanodiscs for Chemo-

immunotherapy against Glioblastoma Multiforme. ACS nano 2019; 13:1365-1384.

[254] Guo Y, Wang D, Song Q et al. Erythrocyte membrane-enveloped polymeric nanoparticles as nanovaccine for induction of antitumor immunity against melanoma. ACS nano 2015; 9:6918-6933. 
[255] Kuai R, Sun X, Yuan W et al. Dual TLR agonist nanodiscs as a strong adjuvant system for vaccines and immunotherapy. Journal of Controlled Release 2018; 282:131-139.

[256] Kuai R, Sun X, Yuan W et al. Subcutaneous nanodisc vaccination with neoantigens for combination cancer immunotherapy. Bioconjugate chemistry 2018; 29:771-775.

[257] Scheetz L, Park KS, Li Q et al. Engineering patient-specific cancer immunotherapies. Nature biomedical engineering 2019; 3:768-782.

[258] Giljohann DA, Seferos DS, Prigodich AE et al. Gene Regulation with Polyvalent siRNA-Nanoparticle Conjugates. Journal of the American Chemical Society 2009; 131:2072-2073.

[259] Sugahara KN, Teesalu T, Karmali PP et al. Tissue-Penetrating Delivery of Compounds and Nanoparticles into Tumors. Cancer Cell 2009; 16:510-520.

[260] Sugahara KN, Teesalu T, Karmali PP et al. Coadministration of a Tumor-Penetrating Peptide Enhances the Efficacy of Cancer Drugs. Science 2010; 328:1031-1035.

[261] Agemy L, Friedmann-Morvinski D, Kotamraju VR et al. Targeted nanoparticle enhanced proapoptotic peptide as potential therapy for glioblastoma. Proceedings of the National Academy of Sciences of the United States of America 2011; 108:17450-17455.

[262] Gregory JV, Kadiyala P, Doherty R et al. Systemic Brain Tumor Delivery of Synthetic Protein Nanoparticles for Glioblastoma Therapy. bioRxiv 2019:862581.

[263] Madhankumar A, Slagle-Webb B, Mintz A et al. Interleukin-13 receptor-targeted nanovesicles are a potential therapy for glioblastoma multiforme. Molecular cancer therapeutics 2006; 5:3162-3169.

[264] Wang B, Lv L, Wang Z et al. Improved anti-glioblastoma efficacy by IL-13R 22 mediated copolymer nanoparticles loaded with paclitaxel. Scientific reports 2015; 5:16589.

[265] Raucher D. Tumor targeting peptides: novel therapeutic strategies in glioblastoma. Current opinion in pharmacology 2019; 47:14-19.

[266] Gao H, Yang Z, Zhang S et al. Ligand modified nanoparticles increases cell uptake, alters endocytosis and elevates glioma distribution and internalization. Scientific reports 2013; 3:2534.

[267] Kang T, Jiang M, Jiang $D$ et al. Enhancing glioblastoma-specific penetration by functionalization of nanoparticles with an iron-mimic peptide targeting transferrin/transferrin receptor complex. Molecular pharmaceutics 2015; 12:2947-2961.

[268] Johnsen KB, Burkhart A, Thomsen LB et al. Targeting the transferrin receptor for brain drug delivery. Progress in neurobiology 2019:101665.

[269] Kim SK, Huang L. Nanoparticle delivery of a peptide targeting EGFR signaling. Journal of controlled release 2012; 157:279-286.

[270] Wei L, Guo X-Y, Yang T et al. Brain tumor-targeted therapy by systemic delivery of siRNA with Transferrin receptor-mediated core-shell nanoparticles. International journal of pharmaceutics 2016; 510:394-405.

[271] Zong T, Mei L, Gao H et al. Synergistic dual-ligand doxorubicin liposomes improve targeting and therapeutic efficacy of brain glioma in animals. Molecular pharmaceutics 2014; 11:2346-2357.

[272] Chou T-C. Theoretical basis, experimental design, and computerized simulation of synergism and antagonism in drug combination studies. Pharmacological reviews 2006; 58:621-681.

[273] Chou T-C. Drug combination studies and their synergy quantification using the Chou-Talalay method. Cancer research 2010; 70:440-446.

[274] Rawal S, Patel MM. Threatening cancer with nanoparticle aided combination oncotherapy. Journal of controlled release 2019.

[275] Rahmani S, Park T-H, Dishman AF, Lahann J. Multimodal delivery of irinotecan from microparticles with two distinct compartments. Journal of controlled release 2013; 172:239-245.

[276] Guo L, Fan L, Pang $Z$ et al. TRAIL and doxorubicin combination enhances anti-glioblastoma effect based on passive tumor targeting of liposomes. Journal of controlled release 2011; 154:93-102.

[277] Lim M, Xia Y, Bettegowda C, Weller M. Current state of immunotherapy for glioblastoma. Nature reviews Clinical oncology 2018; 15:422. 
[278] Han SJ, Zygourakis C, Lim M, Parsa AT. Immunotherapy for glioma: promises and challenges. Neurosurgery Clinics 2012; 23:357-370.

[279] Ostrom QT, Bauchet L, Davis FG et al. The epidemiology of glioma in adults: a "state of the science" review. Neuro-oncology 2014; 16:896-913.

[280] Alphandéry E. Glioblastoma treatments: an account of recent industrial developments. Frontiers in pharmacology 2018; 9:879.

[281] Grossman SA, Ye X, Lesser G et al. Immunosuppression in patients with high-grade gliomas treated with radiation and temozolomide. Clinical Cancer Research 2011; 17:5473-5480.

\section{ANNOTATIONS}

* Ostrom QT, Gittleman H, Truitt G et al. CBTRUS statistical report: primary brain and other central nervous system tumors diagnosed in the United States in 2011-2015. Neuro-oncology 2018; 20:iy1-iv86.

Thorough and comprehensive summary of the epidemiology of primary brain and other central nervous system (CNS) tumors in the United States (US) population from 2011 to 2015. This study includes malignant and nonmalignant CNS tumors.

* Louis DN, Perry A, Reifenberger G et al. The 2016 World Health Organization Classification of Tumors of the Central Nervous System: a summary. Acta Neuropathologica 2016; 131:803-820.

The latest World Health Organization classification of tumors of the CNS, using molecular parameters for the first time, in addition to histology, to define many tumor entities.

** Verhaak RG. Moving the needle: Optimizing classification for glioma. Science translational medicine 2016; $8: 350 \mathrm{fs} 314$.

Easy-to-follow guidelines for the classification of gliomas taking into account molecular data.

** Mackay A, Burford A, Carvalho D et al. Integrated molecular meta-analysis of 1,000 pediatric high-grade and diffuse intrinsic pontine glioma. Cancer cell 2017; 32:520-537. e525.

Comprehensive work on the specific molecular characteristics and classification of pediatric HGG. 
* Engelhardt B, Vajkoczy P, Weller RO. The movers and shakers in immune privilege of the CNS. Nat Immunol 2017; 18:123-131.

Comprehensive review that summarizes the current knowledge on the cellular and molecular mechanisms involved in immune-cell trafficking and lymphatic drainage from the CNS, emphasizing the fact that understanding immune privilege of the CNS requires intimate knowledge of its unique anatomy.

** Negi N, Das BK. CNS: Not an immunoprivilaged site anymore but a virtual secondary lymphoid organ. International reviews of immunology 2018; 37:57-68.

This concise review depicts the current view of the interactions between the immune system and the CNS.

* Quail DF, Joyce JA. The Microenvironmental Landscape of Brain Tumors. Cancer Cell 2017; 31:326-341.

Review discussing the brain tumor microenvironment features, including brain-resident cell types, the blood-brain barrier, and various aspects of its immune-suppressive environment.

** Young JS, Dayani F, Morshed RA et al. Immunotherapy for high grade gliomas: a clinical update and practical considerations for neurosurgeons. World neurosurgery 2019.

This review summarizes the immuno-therapy strategies for high-grade gliomas in completed and ongoing trials until April 2019 and includes recommendations for their practical application in the clinical setting.
ABREVIATIONS
BBB
Blood-Brain Barrier
CAR
Chimeric Antigen Receptor
CNS
Central Nervous System
$\mathrm{CCNU}$
Lomustine
Combination Therapy
Dendritic Cell
DCV
Dendritic Cell Vaccines
DMG
Diffuse Midline Glioma

CT

DC 


$\begin{array}{ll}\text { FDA } & \text { Food And Drug Administration } \\ \text { GBM } & \text { Glioblastoma } \\ \text { HMGB1 } & \text { High Mobility Group Box 1 } \\ \text { i.v. } & \text { Intravenously } \\ \text { IDO1 } & \text { Indoleamine 2,3-Dioxygenase 1 } \\ \text { MS } & \text { Median Survival } \\ \text { NPs } & \text { Nanoparticles } \\ \text { OS } & \text { Overall Survival } \\ \text { OV } & \text { Oncolytic Virus } \\ \text { PFS } & \text { Progression Free Survival } \\ \text { rGBM } & \text { Recurrent Glioblastoma } \\ \text { SOC } & \text { Standard Of Care } \\ \text { TAA } & \text { Tumor-Associated Antigen } \\ \text { TCR } & \text { T-Cell Receptor } \\ \text { TME } & \text { Tumor Microenvironment } \\ \text { TMZ } & \text { Temozolomide } \\ \text { TSA } & \text { Tumor-Specific Antigen } \\ \text { TT-RNA } & \text { Total Tumor RNA } \\ \text { VDX } & \text { Veledimexin } \\ \text { VEGF } & \text { Vascular Endothelial Growth Factor } \\ \end{array}$




\begin{tabular}{|c|c|c|c|c|c|}
\hline $\begin{array}{c}\text { Type of } \\
\text { immunotherap } \\
y\end{array}$ & NCT & Title & Status & Phase & URL \\
\hline $\begin{array}{c}\text { TUMOR } \\
\text { ASSOCIATED } \\
\text { ANTIGENS/PE }\end{array}$ & NCT02507583 & $\begin{array}{l}\text { Antisense102: Pilot } \\
\text { Immunotherapy for Newly } \\
\text { Diagnosed Malignant Glioma }\end{array}$ & Active, not recruiting & Phase-I & $\begin{array}{l}\text { https://ClinicalTri } \\
\text { als.gov/show/NC } \\
\text { T02507583 }\end{array}$ \\
\hline
\end{tabular}

TABLE 1 


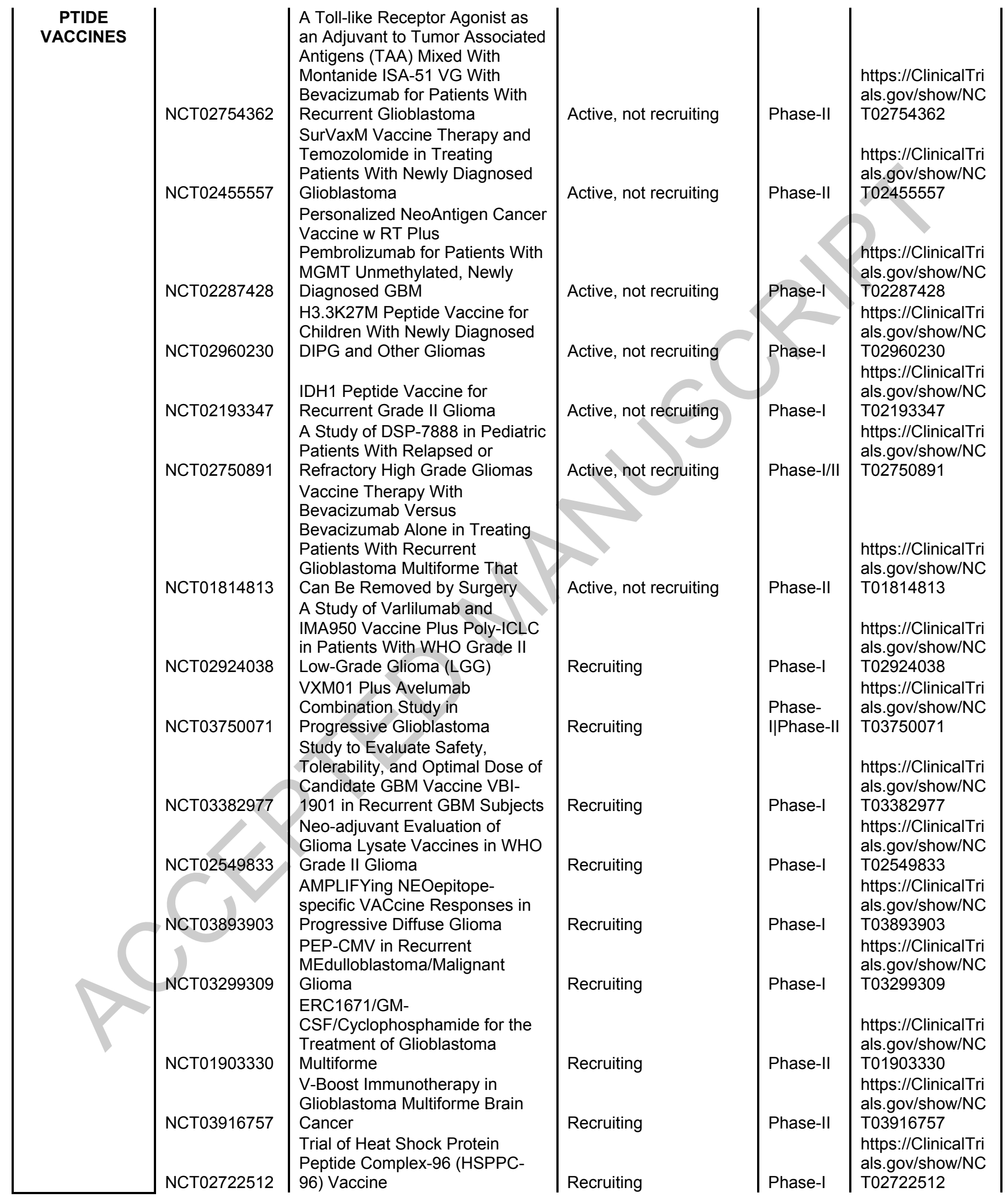




\begin{tabular}{|c|c|c|c|c|c|}
\hline & $\begin{array}{l}\text { NCT03422094 } \\
\text { NCT03018288 } \\
\text { NCT02358187 } \\
\text { NCT03650257 } \\
\text { NCT04015700 } \\
\text { NCT02864368 } \\
\text { NCT04280848 } \\
\text { NCT03223103 } \\
\text { NCT04013672 } \\
\text { NCT03665545 } \\
\text { NCT03382977 } \\
\text { NCT04116658 }\end{array}$ & 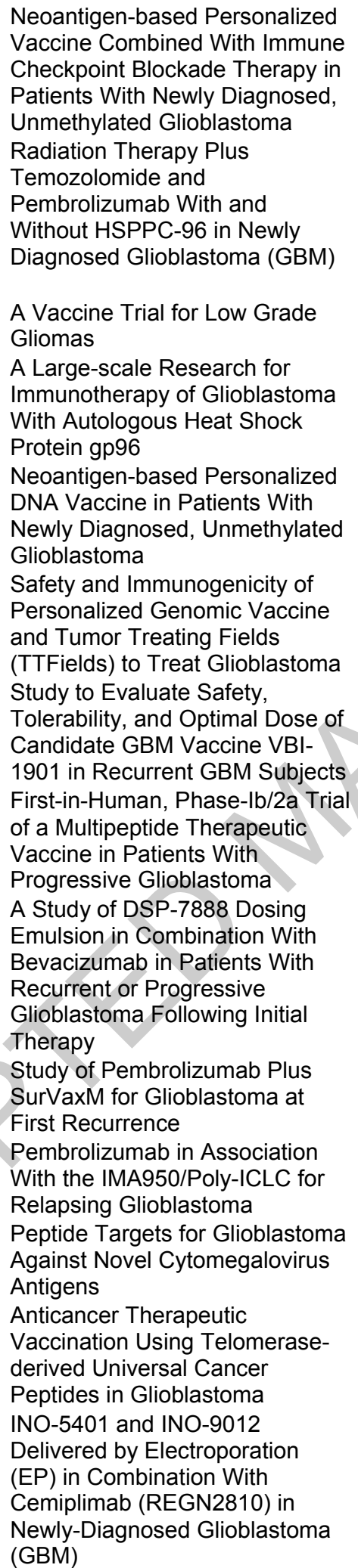 & $\begin{array}{l}\text { Not yet recruiting } \\
\text { Recruiting } \\
\text { Not yet recruiting } \\
\text { Recruiting } \\
\text { Recruiting } \\
\text { Recruiting }\end{array}$ & $\begin{array}{l}\text { Phase-II } \\
\text { Phase-II } \\
\text { Phase- } \\
\text { I|Phase-II } \\
\text { Phase-I } \\
\text { Phase- } \\
\text { I|Phase-II }\end{array}$ & $\begin{array}{l}\text { https://ClinicalTri } \\
\text { als.gov/show/NC } \\
\text { T03422094 } \\
\text { https://ClinicalTri } \\
\text { als.gov/show/NC } \\
\text { T03018288 } \\
\text { https://ClinicalTri } \\
\text { als.gov/show/NC } \\
\text { T02358187 } \\
\text { https://ClinicalTri } \\
\text { als.gov/show/NC } \\
\text { T03650257 } \\
\text { https://ClinicalTri } \\
\text { als.gov/show/NC } \\
\text { T04015700 } \\
\text { https://ClinicalTri } \\
\text { als.gov/show/NC } \\
\text { T03223103 } \\
\text { https://ClinicalTri } \\
\text { als.gov/show/NC } \\
\text { T03382977 } \\
\text { https://ClinicalTri } \\
\text { als.gov/show/NC } \\
\text { T04116658 }\end{array}$ \\
\hline $\begin{array}{l}\text { DENDRITIC } \\
\text { CELL } \\
\text { VACCINES } \\
\end{array}$ & NCT04201873 & $\begin{array}{l}\text { Pembrolizumab and a Vaccine } \\
\text { (ATL-DC) for the Treatment of } \\
\text { Surgically Accessible Recurrent }\end{array}$ & Not yet recruiting & Phase-I & $\begin{array}{l}\text { https://ClinicalTri } \\
\text { als.gov/show/NC } \\
\text { T04201873 }\end{array}$ \\
\hline
\end{tabular}




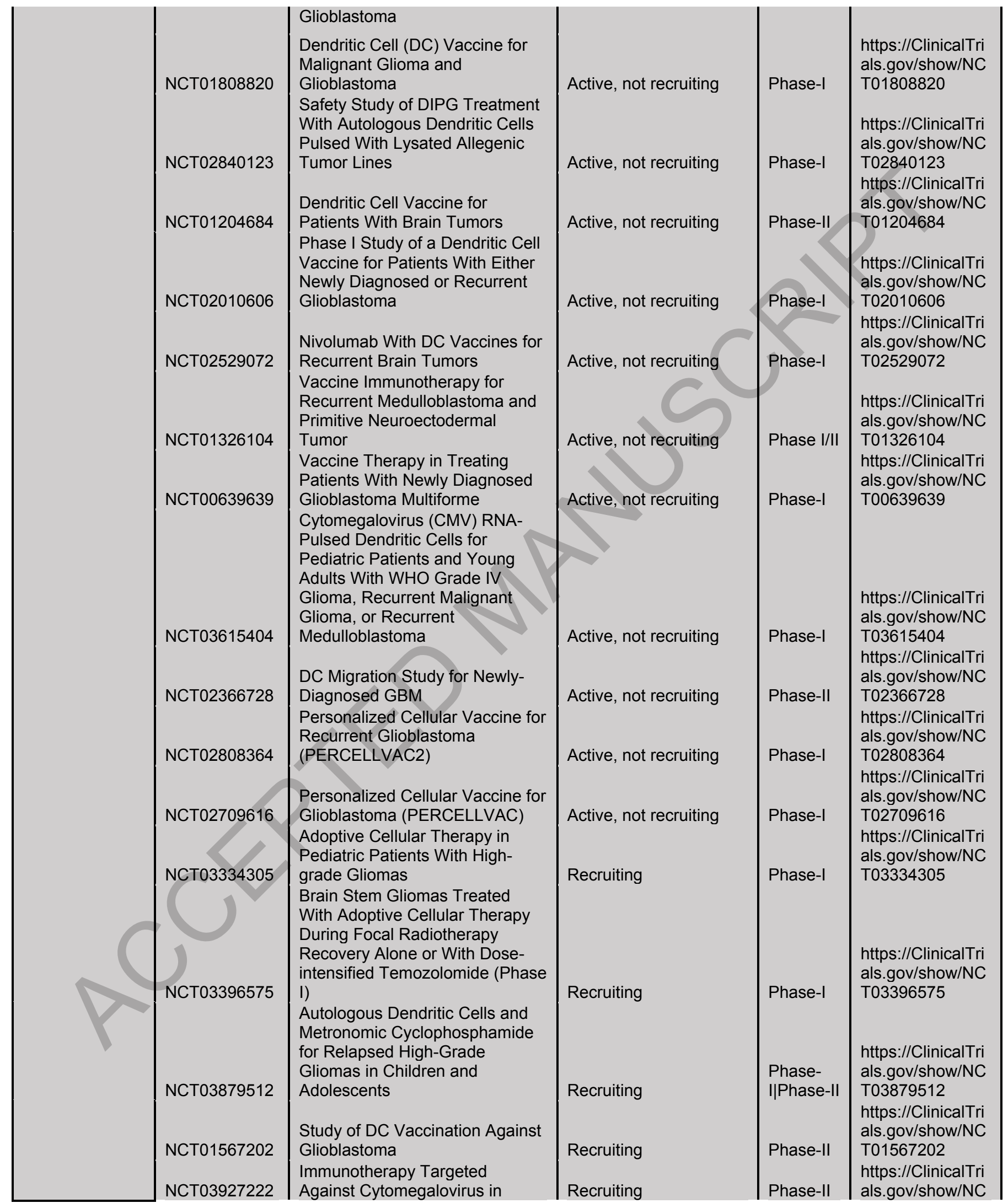




\begin{tabular}{|c|c|c|c|c|c|}
\hline & $\begin{array}{l}\text { NCT02649582 } \\
\text { NCT03395587 } \\
\text { NCT04115761 } \\
\text { NCT03548571 } \\
\text { NCT03400917 } \\
\text { NCT02465268 }\end{array}$ & $\begin{array}{l}\text { Patients With Newly-Diagnosed } \\
\text { WHO Grade IV Unmethylated } \\
\text { Glioma } \\
\text { Adjuvant Dendritic Cell- } \\
\text { immunotherapy Plus } \\
\text { Temozolomide in Glioblastoma } \\
\text { Patients } \\
\text { Efficiency of Vaccination With } \\
\text { Lysate-loaded Dendritic Cells in } \\
\text { Patients With Newly Diagnosed } \\
\text { Glioblastoma } \\
\text { A Phase II, Randomized, Open- } \\
\text { Label, Parallel-Group Study to } \\
\text { Evaluate the Efficacy and Safety } \\
\text { of Autologous Dendritic Cell } \\
\text { Vaccination (ADCV01) as an } \\
\text { Add-On Treatment for Primary } \\
\text { Glioblastoma Multiforme (GBM) } \\
\text { Patients } \\
\text { Dendritic Cell Immunotherapy } \\
\text { Against Cancer Stem Cells in } \\
\text { Glioblastoma Patients Receiving } \\
\text { Standard Therapy } \\
\text { Autologous Dendritic Cells } \\
\text { Loaded With Autologous Tumor } \\
\text { Associated Antigens for } \\
\text { Treatment of Newly Diagnosed } \\
\text { Glioblastoma } \\
\text { Vaccine Therapy for the } \\
\text { Treatment of Newly Diagnosed } \\
\text { Glioblastoma Multiforme }\end{array}$ & $\begin{array}{l}\text { Recruiting } \\
\text { Recruiting }\end{array}$ & $\begin{array}{l}\text { Phase-II } \\
\text { Phase- } \\
\text { II|Phase } \\
\text { III }\end{array}$ & $\begin{array}{l}\text { https://ClinicalTri } \\
\text { als.gov/show/NC } \\
\text { T02649582 } \\
\text { https://ClinicalTri } \\
\text { als.gov/show/NC } \\
\text { T03395587 } \\
\\
\\
\text { https://ClinicalTri } \\
\text { als.gov/show/NC } \\
\text { T04115761 } \\
\text { https://ClinicalTri } \\
\text { als.gov/show/NC } \\
\text { T03548571 } \\
\\
\text { https://ClinicalTri } \\
\text { als.gov/show/NC } \\
\text { T03400917 } \\
\text { https://ClinicalTri } \\
\text { als.gov/show/NC } \\
\text { T02465268 }\end{array}$ \\
\hline $\begin{array}{l}\text { ONCOLYTIC } \\
\text { VIRUS }\end{array}$ & $\begin{array}{l}\text { NCT02798406 } \\
\text { NCT02444546 } \\
\text { NCT03973879 } \\
\text { NCT03576612 } \\
\text { NCT03178032 } \\
\text { NCT03896568 } \\
\text { NCT03072134 } \\
\text { NCT03152318 } \\
\text { NCT03657576 }\end{array}$ & $\begin{array}{l}\text { Combination Adenovirus + } \\
\text { Pembrolizumab to Trigger } \\
\text { Immune Virus Effects } \\
\text { Wild-Type Reovirus in } \\
\text { Combination With Sargramostim } \\
\text { in Treating Younger Patients } \\
\text { With High-Grade Relapsed or } \\
\text { Refractory Brain Tumors } \\
\text { Combination of PVSRIPO and } \\
\text { Atezolizumab for Adults With } \\
\text { Recurrent Malignant Glioma } \\
\text { GMCl, Nivolumab, and Radiation } \\
\text { Therapy in Treating Patients } \\
\text { With Newly Diagnosed High- } \\
\text { Grade Gliomas } \\
\text { Oncolytic Adenovirus, DNX- } \\
\text { 2401, for Naive Diffuse Intrinsic } \\
\text { Pontine Gliomas } \\
\text { Oncolytic Adenovirus DNX-2401 } \\
\text { in Treating Patients With } \\
\text { Recurrent High-Grade Glioma } \\
\text { Neural Stem Cell Based } \\
\text { Virotherapy of Newly Diagnosed } \\
\text { Malignant Glioma } \\
\text { A Study of the Treatment of } \\
\text { Recurrent Malignant Glioma With } \\
\text { rQNestin34.5v.2 } \\
\text { Trial of C134 in Patients With } \\
\text { Recurrent GBM }\end{array}$ & $\begin{array}{l}\text { Recruiting } \\
\text { Recruiting } \\
\text { Recruiting } \\
\text { Recruiting } \\
\text { Recruiting } \\
\text { Recruiting }\end{array}$ & $\begin{array}{l}\text { Phase-I } \\
\text { Phase-I } \\
\text { Phase-I } \\
\text { Phase-I } \\
\text { Phase-I } \\
\text { Phase-I }\end{array}$ & $\begin{array}{l}\text { https://ClinicalTri } \\
\text { als.gov/show/NC } \\
\text { T02798406 } \\
\\
\text { https://ClinicalTri } \\
\text { als.gov/show/NC } \\
\text { T02444546 } \\
\text { https://ClinicalTri } \\
\text { als.gov/show/NC } \\
\text { T03973879 } \\
\text { https://ClinicalTri } \\
\text { als.gov/show/NC } \\
\text { T03576612 } \\
\text { https://ClinicalTri } \\
\text { als.gov/show/NC } \\
\text { T03178032 } \\
\text { https://ClinicalTri } \\
\text { als.gov/show/NC } \\
\text { T03896568 } \\
\text { https://ClinicalTri } \\
\text { als.gov/show/NC } \\
\text { T03072134 } \\
\text { https://ClinicalTri } \\
\text { als.gov/show/NC } \\
\text { T03152318 } \\
\text { https://ClinicalTri } \\
\text { als.gov/show/NC } \\
\text { T03657576 }\end{array}$ \\
\hline
\end{tabular}




\begin{tabular}{|c|c|c|c|c|c|}
\hline & $\begin{array}{l}\text { NCT03294486 } \\
\text { NCT02062827 } \\
\text { NCT03714334 } \\
\text { NCT02457845 } \\
\text { NCT03911388 } \\
\text { NCT02986178 } \\
\text { NCT01491893 } \\
\text { NCT03043391 }\end{array}$ & $\begin{array}{l}\text { Safety and Efficacy of the } \\
\text { ONCOlytic VIRus Armed for } \\
\text { Local Chemotherapy, TG6002/5- } \\
\text { FC, in Recurrent Glioblastoma } \\
\text { Patients } \\
\text { Genetically Engineered HSV-1 } \\
\text { Phase-I Study for the Treatment } \\
\text { of Recurrent Malignant Glioma } \\
\text { DNX-2440 Oncolytic Adenovirus } \\
\text { for Recurrent Glioblastoma } \\
\text { HSV G207 Alone or With a } \\
\text { Single Radiation Dose in } \\
\text { Children With Progressive or } \\
\text { Recurrent Supratentorial Brain } \\
\text { Tumors } \\
\text { HSV G207 in Children With } \\
\text { Recurrent or Refractory } \\
\text { Cerebellar Brain Tumors } \\
\text { PVSRIPO in Recurrent Malignant } \\
\text { Glioma } \\
\text { PVSRIPO for Recurrent } \\
\text { Glioblastoma (GBM) } \\
\text { Phase-Ib Study PVSRIPO for } \\
\text { Recurrent Malignant Glioma in } \\
\text { Children }\end{array}$ & $\begin{array}{l}\text { Recruiting } \\
\text { Recruiting } \\
\text { Recruiting } \\
\text { Active, not recruiting } \\
\text { Recruiting }\end{array}$ & $\begin{array}{l}\text { Phase-II } \\
\text { Phase-I } \\
\text { Phase-I }\end{array}$ & $\begin{array}{l}\text { https://ClinicalTri } \\
\text { als.gov/show/NC } \\
\text { T03294486 } \\
\text { https://ClinicalTri } \\
\text { als.gov/show/NC } \\
\text { T02062827 } \\
\text { https://ClinicalTri } \\
\text { als.gov/show/NC } \\
\text { T03714334 } \\
\\
\text { https://ClinicalTri } \\
\text { als.gov/show/NC } \\
\text { T02457845 } \\
\text { https://ClinicalTri } \\
\text { als.gov/show/NC } \\
\text { T03911388 } \\
\text { https://ClinicalTri } \\
\text { als.gov/show/NC } \\
\text { T02986178 } \\
\text { https://ClinicalTri } \\
\text { als.gov/show/NC } \\
\text { T01491893 } \\
\text { https://ClinicalTri } \\
\text { als.gov/show/NC } \\
\text { T03043391 }\end{array}$ \\
\hline $\begin{array}{r}\text { GEI } \\
\text { THER }\end{array}$ & $\begin{array}{l}\text { NCT03679754 } \\
\text { NCT01811992 } \\
\text { NCT03330197 } \\
\text { NCT02026271 } \\
\text { NCT04006119 } \\
\text { NCT03636477 }\end{array}$ & $\begin{array}{l}\text { Evaluation of Ad-RTS-hIL-12+ } \\
\text { Veledimex in Subjects With } \\
\text { Recurrent or Progressive } \\
\text { Glioblastoma, a Substudy to } \\
\text { ATI001-102 } \\
\text { Combined Cytotoxic and } \\
\text { Immune-Stimulatory Therapy for } \\
\text { Glioma } \\
\text { A Study of Ad-RTS-hIL-12 + } \\
\text { Veledimex in Pediatric Subjects } \\
\text { With Brain Tumors or DIPG } \\
\text { A Study of Ad-RTS-hIL-12 With } \\
\text { Veledimex in Subjects With } \\
\text { Glioblastoma or Malignant } \\
\text { Glioma } \\
\text { Study of Ad-RTS-hIL-12 + } \\
\text { Veledimex in Combination With } \\
\text { Cemiplimab in Subjects With } \\
\text { Recurrent or Progressive } \\
\text { Glioblastoma } \\
\text { A Study of Ad-RTS-hIL-12 With } \\
\text { Veledimex in Combination With } \\
\text { Nivolumab in Subjects With } \\
\text { Glioblastoma; a Substudy to } \\
\text { ATI001-102 }\end{array}$ & $\begin{array}{l}\text { Active, not recruiting } \\
\text { Active, not recruiting } \\
\text { Active, not recruiting } \\
\text { Active, not recruiting } \\
\text { Recruiting }\end{array}$ & $\begin{array}{l}\text { Phase-I } \\
\text { Phase-I } \\
\text { Phase-I }\end{array}$ & $\begin{array}{l}\text { https://ClinicalTri } \\
\text { als.gov/show/NC } \\
\text { T03679754 } \\
\text { https://ClinicalTri } \\
\text { als.gov/show/NC } \\
\text { T01811992 } \\
\text { https://ClinicalTri } \\
\text { als.gov/show/NC } \\
\text { T03330197 } \\
\text { https://ClinicalTri } \\
\text { als.gov/show/NC } \\
\text { T02026271 } \\
\\
\text { https://ClinicalTri } \\
\text { als.gov/show/NC } \\
\text { T04006119 } \\
\text { https://ClinicalTri } \\
\text { als.gov/show/NC } \\
\text { T03636477 }\end{array}$ \\
\hline $\begin{array}{c}\text { IMMUNOSUPP } \\
\text { RESSIVE } \\
\text { CHECKPOINT } \\
\text { INHIBITORS }\end{array}$ & $\begin{array}{l}\text { NCT02794883 } \\
\text { NCT02311920 }\end{array}$ & $\begin{array}{l}\text { Tremelimumab and Durvalumab } \\
\text { in Combination or Alone in } \\
\text { Treating Patients With Recurrent } \\
\text { Malignant Glioma } \\
\text { Ipilimumab and/or Nivolumab in } \\
\text { Combination With Temozolomide } \\
\text { in Treating Patients With Newly } \\
\text { Diagnosed Glioblastoma or }\end{array}$ & Active, not recruiting & Phase-II & $\begin{array}{l}\text { https://ClinicalTri } \\
\text { als.gov/show/NC } \\
\text { T02794883 } \\
\text { https://ClinicalTri } \\
\text { als.gov/show/NC } \\
\text { T02311920 }\end{array}$ \\
\hline
\end{tabular}




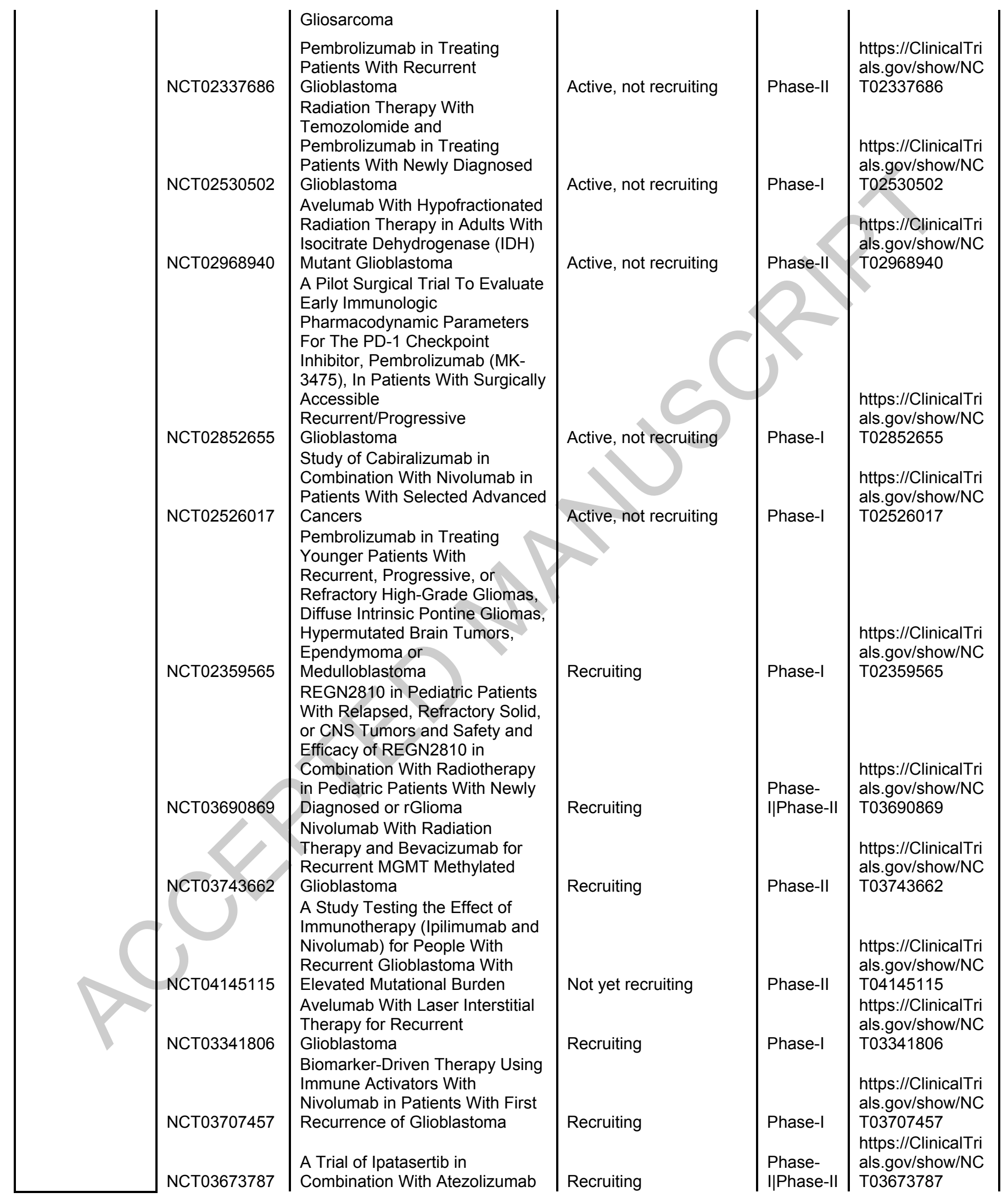


MK-3475 in Combination With MRI-guided Laser Ablation in Recurrent Malignant Gliomas Efficacy of Nivolumab for Recurrent IDH Mutated HighGrade Gliomas

Nivolumab in People With IDH-

Mutant Gliomas With and

Without Hypermutator Phenotype

Nivolumab for Recurrent or Progressive IDH Mutant Gliomas Immune Checkpoint Inhibitor Nivolumab in People With Select

NCT03173950 Rare CNS Cancers

Cytokine Microdialysis for Real-

Time Immune Monitoring in

Glioblastoma Patients

Undergoing Checkpoint

NCT03493932

Blockade

Study of Olaparib and

Durvalumab in IDH-Mutated

NCT03991832 Solid Tumors

Study Testing The Safety and

Efficacy of Adjuvant

Temozolomide Plus TTFields

(OptuneÂ®) Plus Pembrolizumab

in Patients With Newly

Diagnosed Glioblastoma (2-THE-

NCT03405792

TOP)

Translational Study of Nivolumab

in Combination With

Bevacizumab for Recurrent

NCT03890952

Glioblastoma

Nivolumab Plus Standard Dose

Bevacizumab Versus Nivolumab

Plus Low Dose Bevacizumab in

NCT03452579

GBM

Laser Interstitial Thermotherapy

(LITT) Combined With

Checkpoint Inhibitor for

NCT03277638

Recurrent GBM (RGBM)

Atezolizumab in Combination

With Temozolomide and

Radiation Therapy in Treating

Patients With Newly Diagnosed

NCT03174197

Glioblastoma

Intra-tumoral Ipilimumab Plus

Intravenous Nivolumab Following

the Resection of Recurrent

NCT03233152

NCT03047473

Glioblastoma

Avelumab in Patients With Newly

Diagnosed Glioblastoma

Multiforme

Nivolumab, BMS-986205, and

Radiation Therapy With or

Without Temozolomide in

Treating Patients With Newly

\begin{tabular}{l|l} 
NCT04047706 & $\begin{array}{l}\text { Diagnosed Glioblastoma } \\
\text { Pembrolizumab for Newly }\end{array}$
\end{tabular}

NCT03899857

Diagnosed Glioblastoma
Recruiting

Recruiting

Recruiting

Recruiting

Recruiting

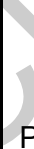

Not yet recruiting

Recruiting

Recruiting

Recruiting

Recruiting

Recruiting

Recruiting

Recruiting

Recruiting

Not yet recruiting
Phase-

I|Phase-II

https://ClinicalTri

als.gov/show/NC

T03174197

https://ClinicalTri als.gov/show/NC

Phase-I

T03233152

https://ClinicalTri

als.gov/show/NC

Phase-II

T03047473

https://ClinicalTri als.gov/show/NC

https://ClinicalTri https://ClinicalTri T03925246

https://ClinicalTri 列 https://ClinicalTri als.gov/show/NC

https://ClinicalTri T03493932

ClinicalTr

https://ClinicalTri T03890952

https://ClinicalTri T03452579

https://ClinicalTri als.gov/show/NC

I|Phase-II T03277638

Phase-

T04047706

https://ClinicalTri

Phase-II als.gov/show/NC 


\begin{tabular}{|c|c|c|c|c|c|}
\hline & $\begin{array}{l}\text { NCT03722342 } \\
\text { NCT03961971 } \\
\text { NCT02336165 } \\
\text { NCT02658981 } \\
\text { NCT03797326 } \\
\text { NCT04225039 } \\
\text { NCT04195139 }\end{array}$ & $\begin{array}{l}\text { TTAC-0001 and Pembrolizumab } \\
\text { Combination phase1b Trial in } \\
\text { Recurrent Glioblastoma } \\
\text { Trial of Anti-Tim-3 in } \\
\text { Combination With Anti-PD-1 and } \\
\text { SRS in Recurrent GBM } \\
\text { Phase-II Study of MEDI4736 in } \\
\text { Patients With Glioblastoma } \\
\text { Anti-LAG-3 Alone \& in } \\
\text { Combination w/ Nivolumab } \\
\text { Treating Patients w/ Recurrent } \\
\text { GBM (Anti-CD137 Arm Closed } \\
\text { 10/16/18) } \\
\text { Efficacy and Safety of } \\
\text { Pembrolizumab (MK-3475) Plus } \\
\text { Lenvatinib (E7080/MK-7902) in } \\
\text { Previously Treated Participants } \\
\text { With Select Solid Tumors (MK- } \\
\text { 7902-005/E7080-G000- } \\
\text { 224/LEAP-005) } \\
\text { Anti-GITR/Anti-PD1/Stereotactic } \\
\text { Radiosurgery, in Recurrent } \\
\text { Glioblastoma } \\
\text { Nivolumab and Temozolomide } \\
\text { Versus Temozolomide Alone in } \\
\text { Newly Diagnosed Elderly } \\
\text { Patients With GBM } \\
\text { Nivolumab in Combination With } \\
\text { Temozolomide and Radiotherapy } \\
\text { in Children and Adolescents With } \\
\text { Newly Diagnosed High- } \\
\text { grade Glioma } \\
\text { Pembrolizumab and } \\
\text { Reirradiation in Bevacizumab } \\
\text { NaÃ ve and Bevacizumab } \\
\text { Resistant Recurrent } \\
\text { Glioblastoma } \\
\end{array}$ & $\begin{array}{l}\text { Recruiting } \\
\text { Not yet recruiting } \\
\text { Recruiting }\end{array}$ & $\begin{array}{l}\text { Phase-II } \\
\text { Phase-II } \\
\text { Phase-II } \\
\text { Phase- } \\
\text { I|Phase-II }\end{array}$ & $\begin{array}{l}\text { https://ClinicalTri } \\
\text { als.gov/show/NC } \\
\text { T03797326 } \\
\text { https://ClinicalTri } \\
\text { als.gov/show/NC } \\
\text { T04225039 } \\
\text { https://ClinicalTri } \\
\text { als.gov/show/NC } \\
\text { T04195139 } \\
\\
\text { https://ClinicalTri } \\
\text { als.gov/show/NC } \\
\text { T04267146 } \\
\text { https://ClinicalTri } \\
\text { als.gov/show/NC } \\
\text { T03661723 }\end{array}$ \\
\hline CAR T-CEL & $\begin{array}{l}\text { NCT03389230 } \\
\text { NCT02208362 } \\
\text { NCT04099797 } \\
\text { NCT04003649 } \\
\text { NCT03726515 } \\
\text { NCT03383978 }\end{array}$ & $\begin{array}{l}\text { Memory-Enriched T Cells in } \\
\text { Treating Patients With Recurrent } \\
\text { or Refractory Grade III-IV Glioma } \\
\text { Genetically Modified T-cells in } \\
\text { Treating Patients With Recurrent } \\
\text { or Refractory Malignant Glioma } \\
\text { C7R-GD2.CAR T Cells for } \\
\text { Patients With GD2-expressing } \\
\text { Brain Tumors (GAIL-B) } \\
\text { IL13Ralpha2-Targeted Chimeric } \\
\text { Antigen Receptor (CAR) T Cells } \\
\text { With or Without Nivolumab and } \\
\text { Ipilimumab in Treating Patients } \\
\text { With Recurrent or Refractory } \\
\text { Glioblastoma } \\
\text { CART-EGFRvIII + } \\
\text { Pembrolizumab in GBM } \\
\text { Intracranial Injection of NK- } \\
\text { 92/5.28.z Cells in Patients With } \\
\text { Recurrent HER2-positive }\end{array}$ & $\begin{array}{l}\text { Recruiting } \\
\text { Recruiting } \\
\text { Not yet recruiting } \\
\text { Recruiting } \\
\text { Recruiting } \\
\text { Recruiting }\end{array}$ & $\begin{array}{l}\text { Phase-I } \\
\text { Phase-I } \\
\text { Phase-I }\end{array}$ & $\begin{array}{l}\text { https://ClinicalTri } \\
\text { als.gov/show/NC } \\
\text { T04003649 } \\
\text { https://ClinicalTri } \\
\text { als.gov/show/NC } \\
\text { T03726515 } \\
\text { https://ClinicalTri } \\
\text { als.gov/show/NC } \\
\text { T03383978 }\end{array}$ \\
\hline
\end{tabular}




\begin{tabular}{|c|c|c|c|c|c|}
\hline & $\begin{array}{l}\text { NCT03941626 } \\
\text { NCT03638167 } \\
\text { NCT03500991 } \\
\text { NCT04077866 } \\
\text { NCT03283631 } \\
\text { NCT03423992 } \\
\text { NCT04270461 } \\
\text { NCT03638206 }\end{array}$ & $\begin{array}{l}\text { Glioblastoma } \\
\text { Autologous CAR-T/TCR-T Cell } \\
\text { Immunotherapy for Solid } \\
\text { Malignancies } \\
\text { EGFR806-specific CAR T Cell } \\
\text { Locoregional Immunotherapy for } \\
\text { EGFR-positive Recurrent or } \\
\text { Refractory Pediatric CNS } \\
\text { Tumors } \\
\text { HER2-specific CAR T Cell } \\
\text { Locoregional Immunotherapy for } \\
\text { HER2-positive } \\
\text { Recurrent/Refractory Pediatric } \\
\text { CNS Tumors } \\
\text { B7-H3 CAR-T for Recurrent or } \\
\text { Refractory Glioblastoma } \\
\text { Intracerebral EGFR-vIII CAR-T } \\
\text { Cells for Recurrent GBM } \\
\text { Personalized Chimeric Antigen } \\
\text { Receptor T Cell Immunotherapy } \\
\text { for Patients With Recurrent } \\
\text { Malignant Gliomas } \\
\text { GD2 CAR T Cells in } \\
\text { DiffuselntrinsicPontine } \\
\text { Gliomas(DIPG) \& Spinal } \\
\text { DiffuseMidline Glioma(DMG) } \\
\text { Study of B7-H3-Specific CAR T } \\
\text { Cell Locoregional } \\
\text { Immunotherapy for Diffuse } \\
\text { Intrinsic Pontine Glioma/Diffuse } \\
\text { Midline Glioma and Recurrent or } \\
\text { Refractory Pediatric Central } \\
\text { Nervous System Tumors } \\
\text { Chimeric Antigen Receptor } \\
\text { (CAR) T Cells With a Chlorotoxin } \\
\text { Tumor-Targeting Domain for the } \\
\text { Treatment of Recurrent or } \\
\text { Progressive Glioblastoma } \\
\text { NKG2D-based CAR T-cells } \\
\text { Immunotherapy for Patient With } \\
\text { r/r NKG2DL+ Solid Tumors } \\
\text { Autologous CAR-T/TCR-T Cell } \\
\text { Immunotherapy for Malignancies } \\
\end{array}$ & $\begin{array}{l}\text { Recruiting } \\
\text { Not yet recruiting } \\
\text { Recruiting } \\
\text { Recruiting } \\
\text { Not yet recruiting }\end{array}$ & $\begin{array}{l}\text { Phase-I } \\
\text { Phase-I } \\
\text { Phase- } \\
\text { I|Phase-II }\end{array}$ & $\begin{array}{l}\text { https://ClinicalTri } \\
\text { als.gov/show/NC } \\
\text { T03941626 } \\
\text { https://ClinicalTri } \\
\text { als.gov/show/NC } \\
\text { T03638167 } \\
\\
\text { https://ClinicalTri } \\
\text { als.gov/show/NC } \\
\text { T03500991 } \\
\text { https://ClinicalTri } \\
\text { als.gov/show/NC } \\
\text { T04077866 } \\
\text { https://ClinicalTri } \\
\text { als.gov/show/NC } \\
\text { T03283631 } \\
\text { https://ClinicalTri } \\
\text { als.gov/show/NC } \\
\text { T03423992 } \\
\text { https://ClinicalTri } \\
\text { als.gov/show/NC } \\
\text { T04196413 }\end{array}$ \\
\hline $\begin{array}{l}\text { ANTIBODY } \\
\text { DELIVERY }\end{array}$ & $\begin{array}{l}\text { NCT02330562 } \\
\text { NCT00337207 }\end{array}$ & $\begin{array}{l}\text { Efficacy of Hypofractionated XRT } \\
\text { w/Bev. + Temozolomide for } \\
\text { Recurrent Gliomas } \\
\text { Stage 1: Marizomib + } \\
\text { Bevacizumab in WHO Gr IV } \\
\text { GBM; Stage 2: Marizomib Alone; } \\
\text { Stage 3: Combination of } \\
\text { Marizomib and Bevacizumab } \\
\text { Bevacizumab in Treating } \\
\text { Patients With Recurrent or } \\
\text { Progressive Glioma } \\
\text { Hypofractionated Stereotactic } \\
\text { Radiotherapy With Bevacizumab } \\
\text { in the Treatment of Recurrent } \\
\text { Malignant Glioma }\end{array}$ & $\begin{array}{l}\text { Active, not recruiting } \\
\text { Active, not recruiting }\end{array}$ & $\begin{array}{l}\text { Phase I/II } \\
\text { Phase-II }\end{array}$ & $\begin{array}{l}\text { https://ClinicalTri } \\
\text { als.gov/show/NC } \\
\text { T01478321 } \\
\\
\text { https://ClinicalTri } \\
\text { als.gov/show/NC } \\
\text { T02330562 } \\
\text { https://ClinicalTri } \\
\text { als.gov/show/NC } \\
\text { T00337207 } \\
\text { https://ClinicalTri } \\
\text { als.gov/show/NC } \\
\text { T01392209 }\end{array}$ \\
\hline
\end{tabular}




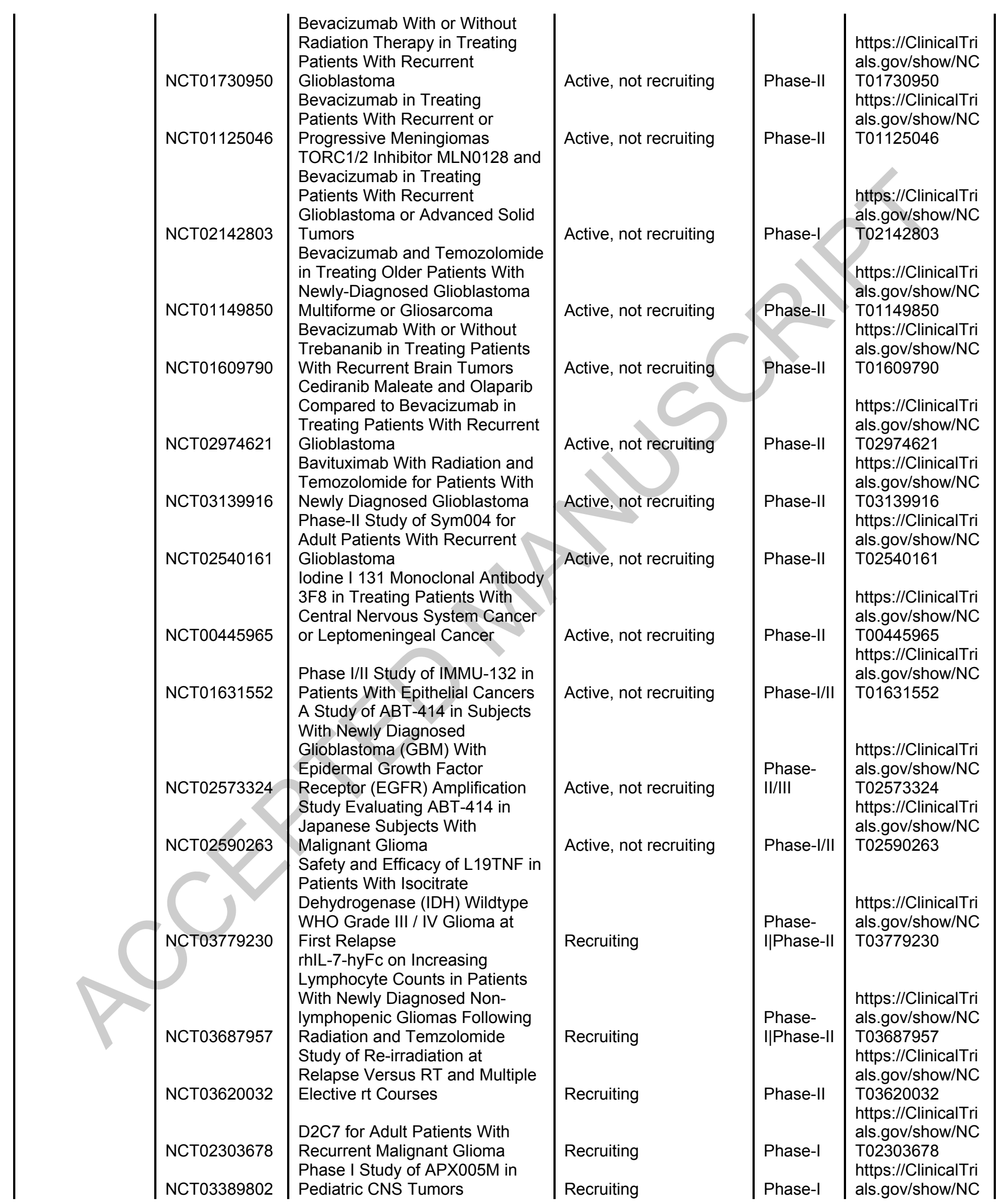




\begin{tabular}{|c|c|c|c|c|c|}
\hline & $\begin{array}{l}\text { NCT03631836 } \\
\text { NCT02800486 } \\
\text { NCT03856099 } \\
\text { NCT03374943 } \\
\text { NCT03618667 } \\
\text { NCT01894061 } \\
\text { NCT03619239 } \\
\text { NCT02669173 } \\
\text { NCT04250064 } \\
\text { NCT04160494 } \\
\text { NCT04178057 }\end{array}$ & $\begin{array}{l}\text { Phase I Study of Monoclonal } \\
\text { Antibondy (GS) 5745, an Matix } \\
\text { Metalloproteinase } 9 \text { (MMP9) Mab } \\
\text { Inhibitor, in Combination With } \\
\text { Bevacizumab in Patients With } \\
\text { Recurrent Glioblastoma } \\
\text { Super Selective Intra-arterial } \\
\text { Repeated Infusion of Cetuximab } \\
\text { (Erbitux) With Reirradiation for } \\
\text { Treatment of } \\
\text { Relapsed/Refractory GBM, AA, } \\
\text { and AOA } \\
\text { TTAC-0001 Phase II Trial With } \\
\text { Recurrent Glioblastoma } \\
\text { Progressed on Bevacizumab } \\
\text { A Trial of KB004 in Patients With } \\
\text { Glioblastoma } \\
\text { GC1118 in Recurrent } \\
\text { Glioblastoma Patients With High } \\
\text { EGFR Amplification } \\
\text { NovoTTF-100A With } \\
\text { Bevacizumab (Avastin) in } \\
\text { Patients With Recurrent } \\
\text { Glioblastoma } \\
\text { Dose-escalation Study to } \\
\text { Evaluate the Safety and } \\
\text { Tolerability of GX-I7 in Patients } \\
\text { With Glioblastoma } \\
\text { Capecitabine + Bevacizumab in } \\
\text { Patients With Recurrent } \\
\text { Glioblastoma } \\
\text { D2C7-IT With Atezolizumab for } \\
\text { Recurrent Gliomas } \\
\text { Phase I Clinical Study of GB222 } \\
\text { to Evaluate the Safety, } \\
\text { Tolerability and PK Profiles. } \\
\text { A Study of Low Dose } \\
\text { Bevacizumab With Conventional } \\
\text { Radiotherapy Alone in Diffuse } \\
\text { Intrinsic Pontine Glioma } \\
\end{array}$ & $\begin{array}{l}\text { Recruiting } \\
\text { Not yet recruiting } \\
\text { Recruiting } \\
\text { Recruiting } \\
\text { Recruiting } \\
\text { Recruiting } \\
\text { Recruiting } \\
\text { Recruiting } \\
\text { Not yet recruiting } \\
\text { Rot ruiting }\end{array}$ & $\begin{array}{l}\text { Phase-II } \\
\text { Phase-II } \\
\text { Phase-I } \\
\text { Phase-II } \\
\text { Phase-II } \\
\text { Phase- } \\
\text { I|Phase-II } \\
\text { Phase-I }\end{array}$ & $\begin{array}{l}\text { https://ClinicalTri } \\
\text { als.gov/show/NC } \\
\text { T03631836 } \\
\\
\text { https://ClinicalTri } \\
\text { als.gov/show/NC } \\
\text { T02800486 } \\
\text { https://ClinicalTri } \\
\text { als.gov/show/NC } \\
\text { T03856099 } \\
\text { https://ClinicalTri } \\
\text { als.gov/show/NC } \\
\text { T03374943 } \\
\text { https://ClinicalTri } \\
\text { als.gov/show/NC } \\
\text { T03618667 } \\
\text { https://ClinicalTri } \\
\text { als.gov/show/NC } \\
\text { T01894061 } \\
\text { https://ClinicalTri } \\
\text { als.gov/show/NC } \\
\text { T03619239 } \\
\text { https://ClinicalTri } \\
\text { als.gov/show/NC } \\
\text { T02669173 } \\
\text { https://ClinicalTri } \\
\text { als.gov/show/NC } \\
\text { T04160494 } \\
\text { https://ClinicalTri } \\
\text { als.gov/show/NC } \\
\text { T04178057 } \\
\text { https://ClinicalTri } \\
\text { als.gov/show/NC } \\
\text { T04250064 }\end{array}$ \\
\hline OTHERS & NCT02415153 & $\begin{array}{l}\text { Pomalidomide in Treating } \\
\text { Younger Patients With } \\
\text { Recurrent, Progressive, or } \\
\text { Refractory Central Nervous } \\
\text { System Tumors } \\
\text { A Study of Pomalidomide } \\
\text { Monotherapy for Children and } \\
\text { Young Adults With Recurrent or } \\
\text { Progressive Primary Brain } \\
\text { Tumors } \\
\text { Epacadostat in Combination With } \\
\text { Radiation Therapy and } \\
\text { Avelumab in Patients With } \\
\text { Recurrent Gliomas } \\
\text { Pediatric Trial of Indoximod With } \\
\text { Chemotherapy and Radiation for } \\
\text { Relapsed Brain Tumors or Newly } \\
\text { Diagnosed DIPG }\end{array}$ & Active, not recruiting & $\begin{array}{l}\text { Phase-II } \\
\text { Phase- } \\
\text { I|Phase-II }\end{array}$ & $\begin{array}{l}\text { https://ClinicalTri } \\
\text { als.gov/show/NC } \\
\text { T02415153 } \\
\text { https://ClinicalTri } \\
\text { als.gov/show/NC } \\
\text { T03257631 } \\
\text { https://ClinicalTri } \\
\text { als.gov/show/NC } \\
\text { T03532295 } \\
\text { https://ClinicalTri } \\
\text { als.gov/show/NC } \\
\text { T04049669 }\end{array}$ \\
\hline
\end{tabular}




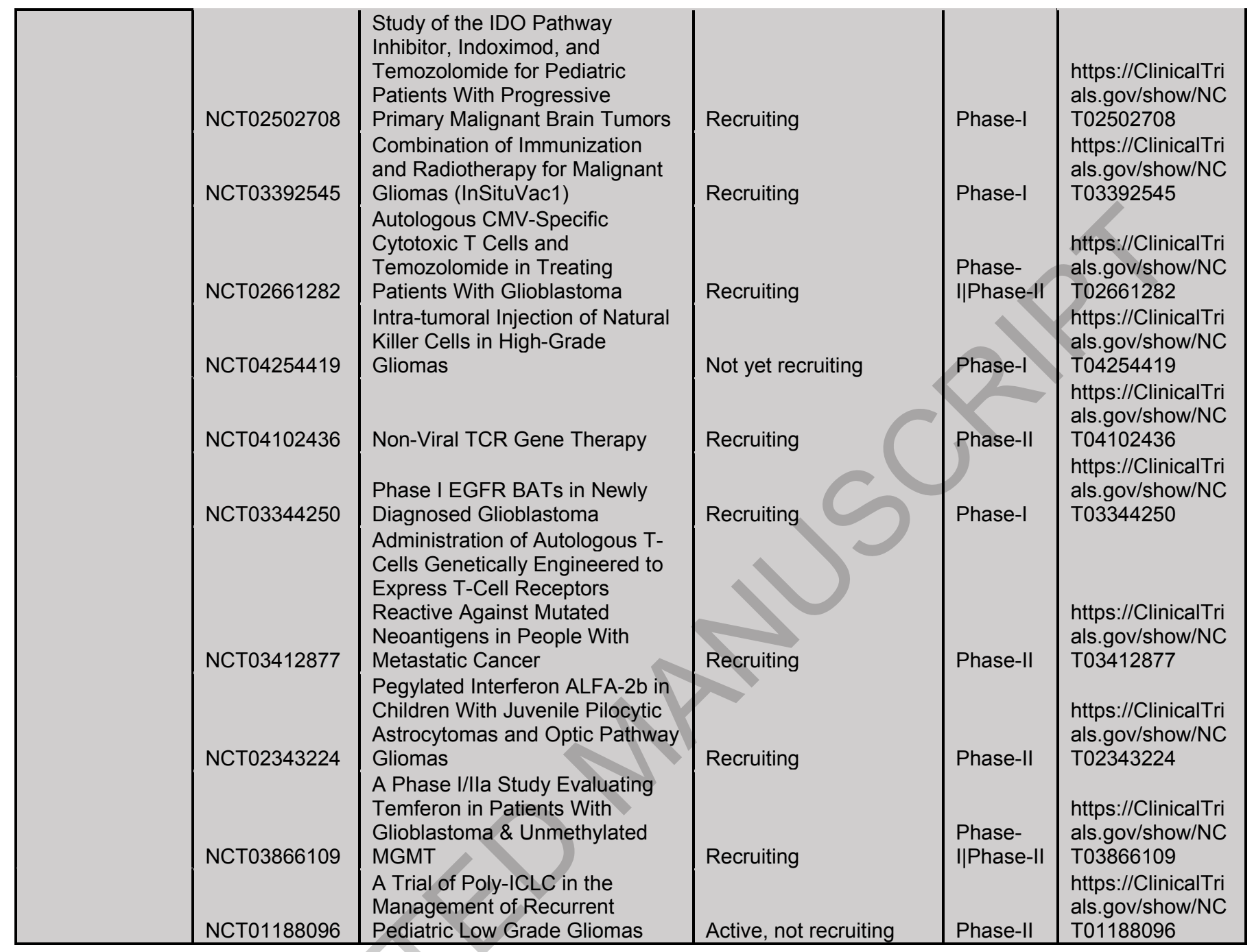

\section{FIGURE LEGENDS}


Figure 1. Immune Checkpoint Inhibitors Therapy for glioma. The immunosuppressive microenvironment, which abrogates the antitumor activity of effector T-cells, is a characteristic of malignant glioma. Within the local tumor microenvironment, glioma cells express PD-L1 that interacts with PD-1 on CD8 T-cells, eliciting immune evasion. Tregs suppress immune responses by secreting cytokines like TGF- $\beta$ and IL-10. These factors shift the activity of resident APCs towards a more tolerogenic state to inhibit T-cell function. The engagement of CD80 on APCs with the self-inhibitory signal receptor CTLA-4 prevents T-cell activation. There is also recruitment and accumulation of myeloid derived suppressor cells, which engage co-inhibitory receptors Tim3 and Lag3 on activated Tcells, suppressing their activity. Immune checkpoint inhibitors, such as monoclonal antibodies targeting PD-1 (i.e., Nivolumab), PD-L1 (i.e., Durvalumab) and CTLA-4 (i.e., Ipilimumab) remove the hurdle and restore the immune response of activating tumor-specific CD8 + T-cells.

Figure 2. Schematic of DC vaccine generation being tested in clinical trials. After tumor resection, tumor cells are used to obtain the lysate or to extract its RNA. Autologous DCs are obtained by isolation of PBMCs by leukapharesis and ex vivo differentiation into monocytic-derived DC. DC could be pulsed with tumor antigens like autologous or allogeneic tumor lysate, TT-RNA, TAA or TSA peptides or with neo-antigens. DCV therapy is combined with adjuvants like GM-CSF, tetanus/diphtheria toxoid or TLR agonist to improve its effect. Combination with the SOC and/or non-standard therapies are being assessed in ongoing trials.

Figure 3: Bicompartmental polymeric particles. A.-C.) Confocal microscopy images of particles where A. shows the PLGA compartment, B. is the PLGA acetal-modified dextran compartment, and C. shows both compartments. D. Scanning Electron Microspcopy image. Scale bar: $10 \mu \mathrm{M}$. Adapted from [275]. 


\section{Figure 1}

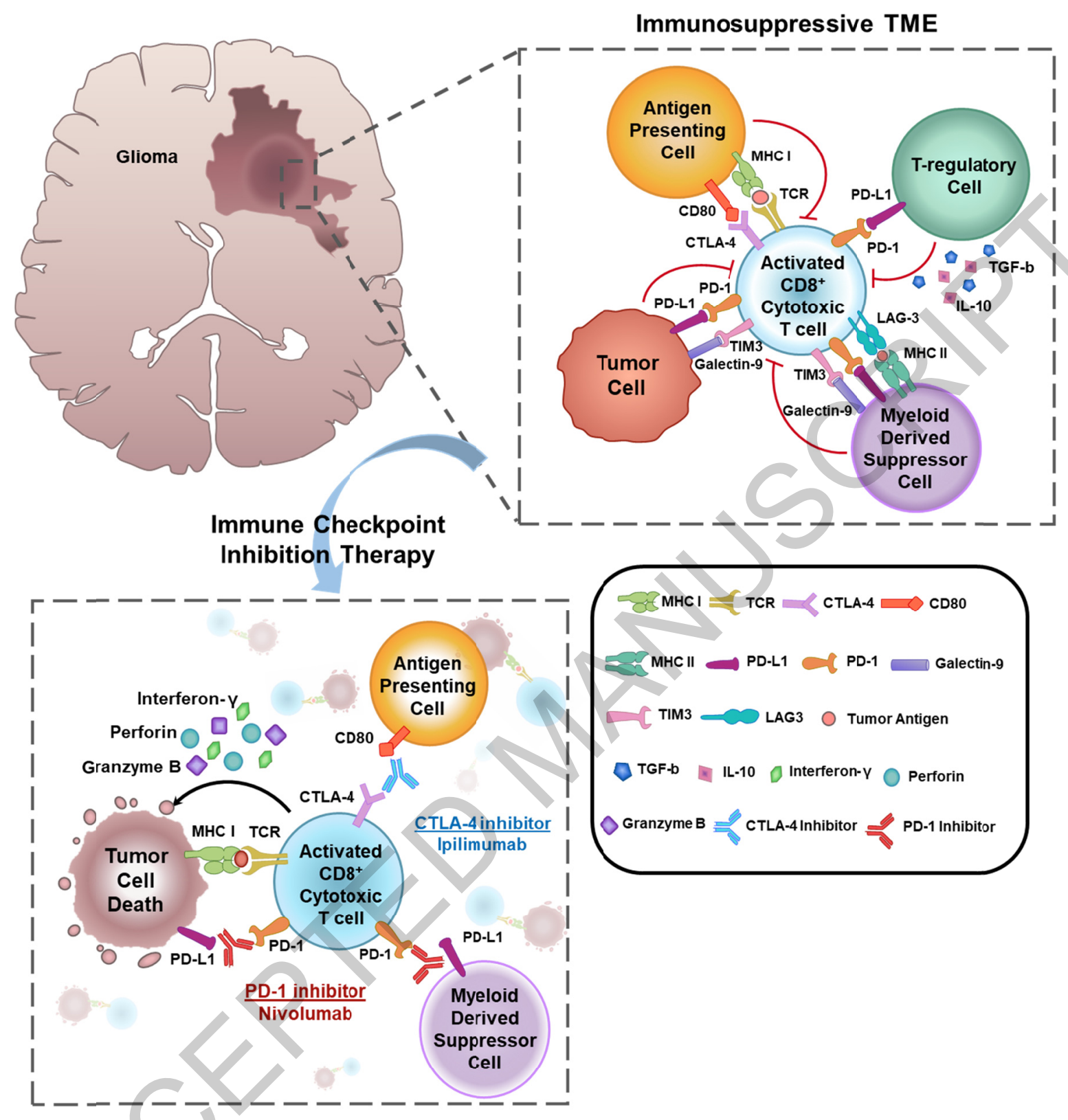

Figure 1. Immune Checkpoint Inhibitors Therapy for glioma. The immunosuppressive microenvironment, which abrogates the antitumor activity of effector T-cells, is a characteristic of malignant glioma. Within the local tumor microenvironment, glioma cells express PD-L1 that interacts with PD-1 on CD8 T-cells, eliciting immune evasion. Tregs suppress immune responses by secreting cytokines like TGF- $\beta$ and IL-10. These factors shift the activity of resident APCs towards a more tolerogenic state to inhibit T-cell function. The engagement of CD80 on APCs with the self-inhibitory signal receptor CTLA-4 prevents T-cell activation. There is also recruitment and accumulation of MDSC, which engage coinhibitory receptors Tim3 and Lag3 on activated T-cells, suppressing their activity. Immune checkpoint inhibitors, such as monoclonal antibodies targeting PD-1 (i.e., Nivolumab), PD-L1 (i.e., Durvalumab) and CTLA-4 (i.e., Ipilimumab) remove the hurdle and restore the immune response of activating tumor-specific CD8 + T-cells. 


\section{Figure 2}

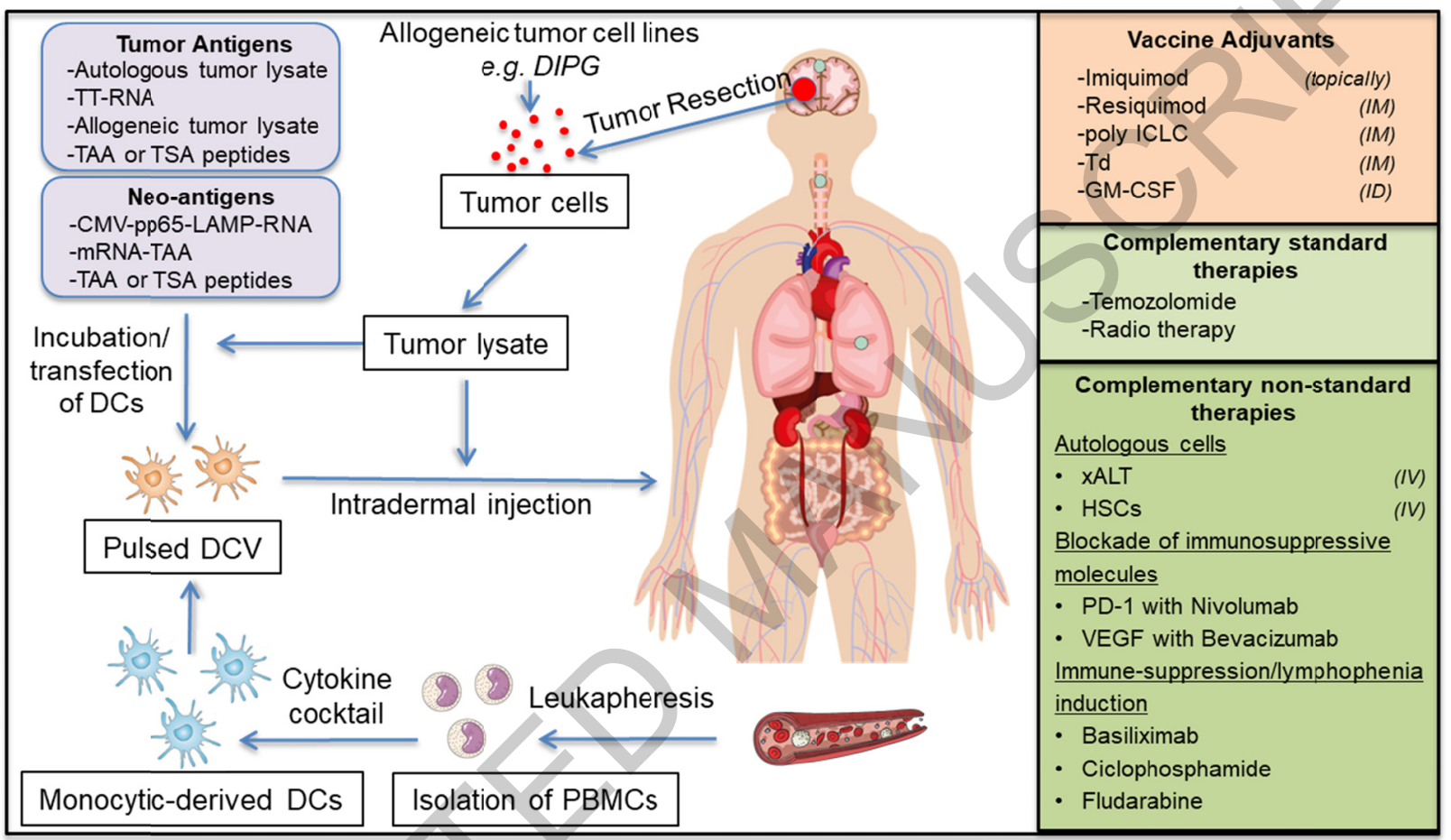

Total tumor RNA (TT-RNA); mRNA tumor autologous antigen (mRNA-TAA); intradermal (ID); intramuscular (IM); intravenous (I.V.); exvivo expanded autologous lymphocyte transfer (XALT); autologous hematopoietic stem cells (HSCs); tetanus/diphtheria toxoid (Td)

Figure 2. Schematic of DC vaccine generation being tested in clinical trials. After tumor resection, tumor cells are used to obtain the lysate or to extract its RNA. Autologous DCs are obtained by isolation of peripheral blood mononuclear cell by leukapheresis and ex vivo differentiation into monocytic-derived DC. DC could be pulsed with autologous or allogeneic tumor lysate, TT-RNA, TAA or TSA peptides or with neo-antigens. DCV therapy is combined with adjuvants like GM-CSF, Td or TLR agonist to improve its effect. Combination with the SOC and/or non-standard therapies are being assessed in ongoing CTs.

\section{Figure 3}



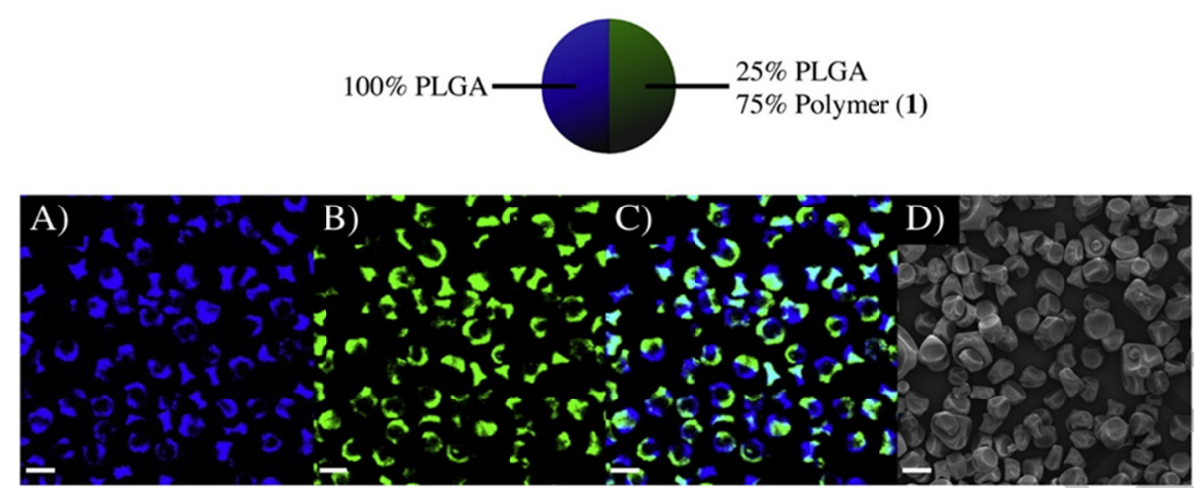

Figure 3: Bicompartmental polymeric particles. A.-C.) Confocal microscopy images of particles where A. shows the PLGA compartment, B. is the PLGA acetal-modified dextran compartment, and C. shows both compartments. D. Scanning Electron Microspcopy image. Scale bar: $10 \mu \mathrm{M}$. Adapted from [268]. 